\title{
Article \\ Cationic and Anionic Dye Adsorption on a Natural Clayey Composite
}

\author{
Carmen Omaira Márquez ${ }^{1,2, * \mathbb{D} \text {, Víctor Julio García }}{ }^{3,4}$, Jefferson Raúl Guaypatin ${ }^{5}$, \\ Francisco Fernández-Martínez ${ }^{6}\left[\right.$ ib and Anita Cecilia Ríos ${ }^{1}$ \\ 1 Facultad de Ingeniería, Carrera de Ingeniera Ambiental, Universidad Nacional de Chimborazo, \\ 060150 Riobamba, Ecuador; arios@unach.edu.ec \\ 2 Facultad de Ciencias Forestales y Ambiental, Universidad de Los Andes, 5115 Mérida, Venezuela \\ 3 Facultad de Ingeniería, Carrera de Ingeniería Civil, Universidad Nacional de Chimborazo, \\ 060150 Riobamba, Ecuador; vgarcia@unach.edu.ec \\ 4 Facultad de Ciencias, Universidad de Los Andes, 5115 Mérida, Venezuela \\ 5 Ministerio del Ambiente y Agua de la Republica de Ecuador, 18010 Ambato, Ecuador; \\ jeffreyguaypa10@gmail.com \\ 6 Departamento de Química de Industrial y Polímeros, Universidad Politécnica de Madrid, \\ 28012 Madrid, Spain; francisco.fernandezm@upm.es \\ * Correspondence: cmarquez@unach.edu.ec; Tel.: +1-0593-983119584
}

Citation: Márquez, C.O.; García, V.J.; Guaypatin, J.R.; Fernández-Martínez, F.; Ríos, A.C. Cationic and Anionic Dye Adsorption on a Natural Clayey Composite. Appl. Sci. 2021, 11, 5127 https://doi.org/10.3390/app11115127

Academic Editor: Stefano Salvestrini

Received: 10 March 2021

Accepted: 25 May 2021

Published: 31 May 2021

Publisher's Note: MDPI stays neutral with regard to jurisdictional claims in published maps and institutional affiliations.

Copyright: (c) 2021 by the authors. Licensee MDPI, Basel, Switzerland. This article is an open access article distributed under the terms and conditions of the Creative Commons Attribution (CC BY) license (https:// creativecommons.org/licenses/by/ $4.0 /)$.

\begin{abstract}
One of the main challenges for environmental sciences today is the effective treatment of dye-laden industrial effluents. This work aimed to study the potential of an untreated (natural occurring clayey composite) red clay (RC) for the adsorption of a cationic dye Basic Navy Blue 2RN (CNB) and anionic dye Drimaren Yellow CL-2R (ADY). We evaluated the effect of pH, dye concentration, and adsorbent concentration on the removal effectiveness to study the absorption process. Also, we studied the adsorption process by analyzing the feasibility of several known adsorption isotherms and kinetic models. The results show that at a $\mathrm{pH}$ of less than 4 , the $\mathrm{CNB}$ and ADY removal percentages were $97 \%$ and $96 \%$, respectively. At a $\mathrm{pH}$ greater than 8 , the CNB and ADY removals were $75 \%$ and $25 \%$, respectively. The CNB adsorption happened by chemisorption of a monolayer on iron-containing particles (IPs). In congtrast, the ADY adsorption occurred by monolayer physisorption on kaolinite particles (KPs) and Na, K-rich Laumontite particles (LPs). The Langmuir isotherm model fits very well with CNB experimental data. The Temkin model shows the best fit between the isotherm function and the ADY dye-adsorption data. The pseudo-secondorder kinetic model fits the CNB and ADY dye-adsorption data on RC particles. The heterogeneous composition of naturally occurring clay favors different adsorption mechanisms and opens an avenue for the separation process's engineering.
\end{abstract}

Keywords: clayey composite; adsorption isotherm; adsorption kinetic; anionic dye adsorption; dye adsorption; basic navy blue 2RN; cationic dye adsorption; drimaren yellow CL-2R

\section{Introduction}

The agricultural and industrial sectors consume $70 \%$ and $22 \%$ of the available freshwater, respectively. This consumption results in large amounts of wastewater [1] and leads to worldwide freshwater availability changes [2]. In particular, dyes' discharge to effluents can reach up to $50 \%$ of the initially used amount in the textile industry, depending on substrate and dye type [3]. Dyes' discharge to effluents and climate variation, among other issues, are emerging threats to water and food $[2,4]$ that have endangered the equilibrium of natural ecosystems. Dyes are recalcitrant organic molecules, resistant to aerobic digestion, and stable to light, heat, and oxidizing agents [5]. Because of dyes' potential toxicity to human health, many have been classified as hazardous pollutants [6]. Dyes potentially alter the genetic constitution by changing the deoxyribonucleic acid (DNA). They are considered 
to be mutagenic and genotoxic chemical agents. Therefore, the discharge of dyes on water bodies is a significant environmental contamination source [4,7]. Dyes tend to sequester metal and may cause microtoxicity to fish and other organisms [1]. At present, around 100,000 dyes exist and are toxic beyond the threshold level. This number is gradually increasing and constitutes a threat to the biosphere. As such, it is crucial to treat colored effluents for the removal of dyes [8].

Dyes organic compounds are based on functional groups such as the chromophore group $\left(\mathrm{NR}_{2}, \mathrm{NHR}, \mathrm{NH}_{2}, \mathrm{COOH}\right.$, and $\left.\mathrm{OH}\right)$ and auxochromes $\left(\mathrm{N}_{2}, \mathrm{NO}\right.$, and $\left.\mathrm{NO}_{2}\right)$ [3]. There are different dyes: acid, basic, disperse, direct, reactive, solvent, sulfur, and vat dyes, amount others $[1,3]$. Several treatment methods have been developed to treat colored effluents: biological treatment, membrane separation, chemical oxidative processes, electrochemical processes, and adsorption processes [9]. However, one factor to consider within the existing alternatives is the treatments' high investment and operating costs, energy expenditure, and the waste generated [10]. The adsorption process is a promising technique to treat wastewater, which utilizes natural materials as an adsorbent. It is regarded as eco-friendly and economical to operate. The adsorbent in the highest demand is activated carbon, due to its adsorption capacity [11], because of its large specific surface area [12]. However, active carbon has some drawbacks, primarily related to its high cost and complicated regeneration process [13]. Alternatively, dye removal by clay has shown promising results. Clays are suitable adsorbent materials for the adsorption of various pollutants because of their: high surface area, porosity, thermal stability, specific active sites, high cation exchange capacity, easy availability, and attractive adsorptive properties [14].

Clay refers to a material that: (1) occurs naturally on the earth's surface, (2) is composed primarily of colloidal grains of minerals, (3) forms a viscous, plastic mass when mixed with water, and (4) hardens and holds its shape when dried or baked. The naturalpristine clays' constituents are mineral clays and associated minerals. Mineral clay provides plasticity, e.g., kaolinite, montmorillonite, illite, and vermiculite. It hardens when dried or fired. The associated minerals do not impart plasticity to clay, e.g., micas, quartz, feldspars, and others: iron oxide; hydroxides such as magnetite, hematite, maghemite, goethite; and aluminum hydroxides such as corundum, gibbsite, boehmite, diaspores. Therefore, natural clays are a mixture of weathered minerals that give rise to unique clayey composite materials. These differences among the clays provide an opportunity to investigate the adsorption potential of these naturally occurring clayey composites as multifunctional adsorbents of pollutants like dyes.

Clays have shown the potential to remove dyes in aqueous solutions [4]. Bentonite removed $88 \%$ of acid dyes [15]. Dolomite $\left(\mathrm{CaMg}\left(\mathrm{CO}_{3}\right)_{2}\right)$ rich natural clay removed $90 \%$ of methylene blue [14]. Smectite-rich natural clay removed $80 \%$ of acid brow 75 [16]. Natural red clay removed $96 \%$ of bright green dye [17]. The adsorption capacity of clays generally results from a net negative charge on the structure of minerals. This negative charge gives clays the capability to adsorb positively charged molecules [18]. Comparatively, clay adsorbents are more cost-effective than active carbon and other organic adsorbents for effluent treatment [3]. Moreover, clay adsorbents reduce costs ten to more times than other adsorbents (Table 1).

Table 1. The effective cost of effluent treatment with clay and other adsorbents [3].

\begin{tabular}{cccc}
\hline Adsorbent & USD \$/kg & Adsorbent & USD \$/kg \\
\hline Bentonite & $0.05-0.3$ & Active carbon & $0.8-1.1$ \\
Red mud & 0.025 & Chitin & $15-20$ \\
Clinoptilolite & $0.14-0.29$ & Chitosan & $16-10$ \\
Natural zeolite & 0.08 & Cross-linked chitosan & $5-10$ \\
\hline
\end{tabular}

Even though many studies deal with clay material as adsorbents, a great deal of work still needs to be done $[1,3,19]$. There exists a wide variety of dyes, and their removal is based on various factors, which include: adsorbate (dye)-adsorbent (clay) relationships 
(interactions), adsorbate molecular size, and the role of functional groups on both adsorbate as well as adsorbent. More detailed work on these interactions is needed for the studies to correlate and compare [1].

Composite materials made up of nanomaterial, bio-material, and mineral clay can improve the dye removal effectiveness. However, their cost still hampers practical application. Clayey composites are low-cost adsorbents with unique properties and structural diversity, offering superior performance versus individual clay mineral counterparts. This research aimed to study a clayey composite-naturally occurring red clay-from Ecuador's Amazonia region as a multifunctional adsorbent to treat dye-laden textile industrial effluents. We selected as adsorbate a cationic dye (Basic Navy Blue 2RN) and an anionic dye (Drimaren Yellow CL-2R) to achieve this objective. We evaluated the effect of $\mathrm{pH}$, adsorbate (dye), and adsorbent (red clay) concentration on the removal effectiveness to study the absorption process. Also, we studied the adsorption process by analyzing the feasibility of several known adsorption isotherms and kinetic models.

\section{Materials and Methods}

\subsection{Materials and Reagents}

Archroma (Reinach, Switzerland) provided the CNB dye-Basic Navy Blue 2RN-and the ADY dye-Drimaren Yellow CL-2R — of very high purity (99\%), taken as a pollutants model without any prior purification. Chemical and reagents used were of analytical grade, i.e., sulfuric acid $\left(\mathrm{H}_{2} \mathrm{SO}_{4}\right)$, sodium chlorite $\left(\mathrm{NaClO}_{2}\right), \mathrm{HCl}$, and sodium hydroxide $(\mathrm{NaOH})$ were purchased from Sigma-Aldrich Corp., St Louis, MO, USA. Distilled and de-ionized water was used in all experimental work.

The red clay (RC) samples were collected from a natural deposit at the Province of Pastaza Ecuador (UTM coordinates $x=846,551, y=9,854,823$ ). Red clay samples were dried at $105^{\circ} \mathrm{C}$ for $24 \mathrm{~h}$, mechanically ground in a planetary mill, and reduced to powder in an agate mortar.

\subsection{SEM and EDS Characterization}

Morphological analysis was performed with the scanning electron microscope (VEGA 3 TESCAM, Kohoutovice, Czech Republic). The sample was fixed in a sample holder using carbon tape (double-sided) and then coated with a thin layer of gold. Energy dispersive spectroscopy of X-ray photon (EDS) was performed to quantify the sample elemental composition. We scan and sample a rectangle area covering the whole image and performed a mapping with quantitative spectrum analysis. The process involved an accurate standardless spectrum analysis based on the P/B-ZAF method.

\subsection{X-ray Diffraction Characterization}

The RC crystalline phases were analyzed via the powder method. We used an X-ray diffractometer (D8 Advance, Bruker, Billerica, MA USA) equipped with a copper anode $(\lambda=1.5418 \AA)$ and a linear detector (LYNXEYE compound silicon strip detector, Bruker). The diffractograms were collected in a range of 4 to 80 degrees using a step size of 0.02 degrees and a measurement time of $2 \mathrm{~s}$ per step. The diffractogram analysis and the qualitative phase analysis were performed using the QualX program [20]. QualX can carry out the phase identification by inquiring about the PDF-2 commercial database and the freely available database: POW_COD. The POW_COD was created by using the structure information contained in the Crystallography Open Database.

\subsection{Vis-NIR Diffused Reflectance Spectroscopy}

A portable spectroradiometer (Fieldspec ${ }^{\circledR} 4$ radiometer, Analytical Spectral Devices Inc., Boulder, CO, USA) was used to record the diffuse reflectance (DR) spectra. The spectroradiometer was used in a proximal mode over the Vis-NIR region (350-2500 nm). The DR spectrum was recorded by illuminating the sample with a $75 \mathrm{~W}$ Lowel Pro-Light lamp at $45^{\circ}$. The radiometer's optic was vertically aligned with the axis passing through 
the samples' geometric center. Its height was adjusted so that only light reflected from the materials' surface filled the instrument's field of view. A spectralon panel (Labsphere Inc., North Sutton, NH, USA) with 99\% reflectance was used as a reference panel (white reference) to optimize the spectroradiometer before taking Vis-NIR reflectance measurements for each sample. The spectroradiometer's internal configuration consists of three detectors, each collecting spectra from three different spectral regions: 350-1000 nm (Silicon array detector), 1000-1800 nm (InGaAs detector), and 1800-2500 nm (InGaAs detector). The spectra collected by these detectors were not spliced, so each spectrum was corrected, splicing the three aforementioned spectral regions and using the ASD ViewSpec ProTM software (ASD Inc., Boulder, CO, USA). Spectra were recorded consecutively in different angular orientations to eliminate undesirable effects in the spectrum. The spectral was recorded by placing $10 \mathrm{~g}$ of the RC in a Petri dish and placed under the lens (3-10 nm, inclination $90^{\circ}$, height $1.5 \mathrm{~cm}$ ) separated from the sample. Ten spectra were taken (for $4 \mathrm{~s}$ ) in 4 quadrants $\left(0^{\circ}, 90^{\circ}, 180^{\circ}, 270^{\circ}\right)$, obtaining a total of 40 readings for each sample. Spectral reflectance data for each sample were generated by arithmetic averaging four replicated measurements (40 spectra) for that sample. Finally, the readings were normalized to one. We used the Savitzky-Golay algorithm (second-order polynomial and window of 10 wavelengths), implemented in the Origin Lab 9.1 platform (OriginLab Corp., Northampton, MA, USA) to calculate the first derivative of the DR spectra. The DR spectrum first derivative makes feasible spectrum features visualization.

\subsection{Adsorption Test}

Stock solutions of $1 \mathrm{~g} / \mathrm{L}$ of CNB and ADY dyes were prepared by dissolving each dye's appropriated amount in double-distilled water. The used concentrations were obtained by dilution. Adsorption experiments were conducted at room temperature in $50 \mathrm{~mL}$ of dyed water in a flask at a constant agitation speed by varying the $\mathrm{pH}$ of the solution from 2 to 10 , the adsorbent dosage from 0.2 to $1.2 \mathrm{~g} / 50 \mathrm{~mL}$, the contact time from 5 to $60 \mathrm{~min}$, and the initial dye concentration from 15 to $75 \mathrm{mg} / \mathrm{L}$. The $\mathrm{pH}$ was adjusted to a given value by adding analytical grade $\mathrm{H}_{2} \mathrm{SO}_{4}(1 \mathrm{~N})$ and $\mathrm{NaOH}(1 \mathrm{~N})$ reagents. The test solutions were agitated with an IKA shaker, model RT 10 power, IKA ${ }^{\circledR}$ WERKE (Staufen, Germany). Solutions were agitated at $200 \mathrm{rpm}$ at room temperature $\left(20^{\circ} \mathrm{C}\right)$ for 30 minutes until the adsorption process reached equilibrium. Then, samples were centrifugated with a Thermo Fisher Scientific CL2 centrifuge (Waltham, Massachusetts, USA) at $1000 \mathrm{rpm}$ for 30 minutes to separate the liquid phase and solids. Upon centrifugation, filtration was carried out to separate adsorbents' filtration and residue with $0.1 \mu \mathrm{m}$ of membrane filter (Millipore, Japan). The absorbance of the filtrated solution was measured at a wavelength of $\lambda_{\mathrm{ADY}}=420 \mathrm{~nm}$ and $\lambda_{\mathrm{CNB}}=650 \mathrm{~nm}$ with DR $5000 \mathrm{Hach}^{\circledR}$ UV-visible spectrometer (Loveland, Colorado, USA). The CNB dye shows a peak absorbance at $610 \mathrm{~nm}$. However, the CNB dye optical density was measured at $650 \mathrm{~nm}$ to mitigate the azo group hyperchromic effect [21].

The residual dye concentration at the equilibrium state $\left(C_{e} ; \mathrm{mg} / \mathrm{L}\right)$ in the filtrated solution is calculated using Equation (1) upon measuring the calibration curve (optical absorbance vs. dye concentration). The adsorption performance is described by the amount of adsorbate adsorbed or adsorption capacity at equilibrium $\left(q_{e} ; \mathrm{mg} / \mathrm{g}\right)$. Alternatively, the performance is described by the removed adsorbate's relative amount $(\% R)$. The adsorption capacity and the percentage of dye removal are calculated using Equations (2) and (3). In these equations, the $C_{o}$ represents the initial dye concentration expressed in $\mathrm{mg} / \mathrm{L}, V$ is the label for the total volume of the solution expressed in $\mathrm{L}$, and $m$ represents the absorbent mass in grams. In this study, we carried out three replications of each adsorption experiment.

$$
\begin{gathered}
C_{e}=\frac{\text { Optical absorption }}{\text { Calibration constant }} \\
q_{e}=\left(C_{o}-C_{e}\right)\left(\frac{V}{m}\right)
\end{gathered}
$$




$$
\% R=\left(1-\frac{C_{e}}{C_{o}}\right) \times 100
$$

\subsection{Adsorption Isotherm Modeling}

The adsorption equilibria data is crucial to understand how much of the adsorbate can fit onto the solid adsorbent surface. The adsorption isotherm models express a mathematical relation between the dye adsorbed and the remained dye concentration in solution. There are many possible interactions between the adsorbent and the adsorbate. Various isotherm models consist of different model parameters [21]. Therefore, we studied the adsorption equilibria data by analyzing the Langmuir, Freundlich, Tempkin, and DubininRadushkevich isotherm models' feasibility. The criterion for choosing the more feasible isotherm model was that it should be a good fit between the isotherm function and the experimental data. The best-fit isotherm model was determined by carrying out linear regressions of the isotherm linear equation. Data evaluation was accomplished by using $R^{2}$ value analysis.

The Langmuir model (LM) was developed using the following assumptions [22-24]: (1) a fixed number of accessible sites are available on the adsorbent surface, and all active sites have the same energy, (2) adsorption is reversible, (3) once the adsorbate occupies a site, no further adsorption can occur on that site (the adsorbate forms a monolayer on the adsorbent surface), and (4) there is no interaction between adsorbate species. The nonlinear and the Lineweaver-Burk linearization of the LM are described in Equation (4). The LM parameters are found when $1 / q_{e}$ plotted vs. $1 / C_{e}$ yielding a straight line with $1 / q_{m} C_{e}$ the slope and $1 / q_{m}$ intercept.

$$
q_{e}=\frac{q_{m} K_{L} C_{e}}{1+K_{L} C_{e}} \text { and } \frac{1}{q_{e}}=\left(\frac{1}{q_{m} K_{L}}\right) \frac{1}{C_{e}}+\frac{1}{q_{m}}
$$

where $q_{e}\left(\mathrm{mg} \mathrm{g}^{-1}\right)$ is the adsorbed amount uptake at equilibrium, $q_{m}\left(\mathrm{mg} \mathrm{g}^{-1}\right)$ is the maximum possible adsorption $\left(\mathrm{mg} \mathrm{g}^{-1}\right)$ or maximum adsorption capacity of an adsorbent, $K_{L}\left(\mathrm{~L} \mathrm{mg}^{-1}\right)$ is a constant related to the affinity between an adsorbent and adsorbate.

The LM's essential characteristic can be expressed in terms of a dimensional constant called the separation factor or equilibrium parameter $R_{L}$, defined in Equation (5). The adsorption nature is: linear when $R_{L}=1$, favorable when $R_{L}<1$ (concave shape), and unfavorable when $R_{L}>1$ (convex shape) [24].

$$
R_{L}=\frac{1}{1+K_{L} C_{0}}
$$

The Freundlich model (FM) describes the equilibrium data and adsorption characteristics for a heterogeneous surface [25]. The nonlinear and the linear forms of the FM are described in Equation (6). The LM parameters can be found when $\log q_{e}$ plotted vs. $\log C_{e}$ yielding a straight line with $n$ the slope and $\log K_{F}$ intercept.

$$
q_{e}=K_{F} C_{e}^{n} \text { and } \log q_{e}=n \log C_{e}+\log K_{F}
$$

In Equation (6) $K_{F}\left[(\mathrm{mg} / \mathrm{g}) /(\mathrm{mg} / \mathrm{L})^{n}\right]$ is the Freundlich constant and $n$ is the Freundlich intensity parameter. The adsorption nature is linear when $n=1$, favorable when $n<1$ (concave shape), and unfavorable when $n>1$ (convex shape).

The Temkin model (TM) assumes that adsorption heat $\left(\Delta H_{a d s}\right)$ as a function of all molecules' temperature in the layer declines linearly rather than logarithmically due to the surface coverage increase [21,26]. Equation (7) describes the nonlinear and linear forms of the TM. By plotting $q_{e}$ vs. $\ln C_{e}$, both $A_{T}$ and $b_{T}$ constants can be obtained.

$$
q_{e}=\frac{R T}{b_{T}} \ln \left(A_{T} C_{e}\right) \text { and } q_{e}=\frac{R T}{b_{T}} \ln A_{T}+\left(\frac{R T}{b_{T}}\right) \ln C_{e}
$$


In Equation (7), $R$ is the constant of the ideal gases $\left(8.314 \mathrm{~J} \mathrm{~mol}^{-1} \mathrm{~K}^{-1}\right) . T$ is the temperature at which the adsorption was performed $(\mathrm{K})$. The $b_{T}$ is a dimensionless constant related to the heat of adsorption. The $A_{T}$ is the isothermal equilibrium binding constant $\left(\mathrm{L} \mathrm{g}^{-1}\right)$. The $R T / b_{T}$ is the adsorption energy $\left(\mathrm{J} \mathrm{mol}^{-1}\right)$.

The Dubinin-Radushkevich model (D-RM) was developed to account for an adsorbent's porous structure $[23,27]$. Similarly to the model mentioned above, Equation (8) describes the D-RM's nonlinear and linear forms.

$$
\begin{gathered}
q_{e}=q_{m} e^{-K_{D R} \varepsilon^{2}} \text { and } \ln q_{e}=-K_{D R} R^{2} T^{2} \ln ^{2}\left(1+\frac{1}{C_{e}}\right)+\ln q_{m} \\
\varepsilon=R T \ln \left(1+\frac{1}{C_{e}}\right) \text { and } E=\frac{1}{\sqrt{2 K_{D R}}}
\end{gathered}
$$

In Equation (8) $K_{D R}$ is the activity coefficient related to the average free energy of adsorption $\left(\mathrm{mol}^{2} \mathrm{~kJ}^{-2}\right) . \varepsilon$ is the potential energy, also called Polanyi potential. $E$ is the average adsorption energy $\left(\mathrm{kJ} \mathrm{mol}^{-1}\right)$. By plotting $\ln q_{e}$ vs. $\ln ^{2}\left(1+1 / C_{e}\right)$, both $K_{D R}$ and $q_{m}$ constants can be obtained.

\subsection{Adsorption Kinetic Modeling}

The adsorption kinetic data is vital to understanding the adsorption rate, the reaction pathways and adsorption mechanisms, and predicting the rate-controlling step [23]. The adsorption kinetic models express a mathematical relation between the absorbate adsorbed and time. There are different adsorption mechanisms; therefore, various phenomenological models describing adsorption kinetics, consisting of different model parameters. We studied the adsorption kinetic data by analyzing the pseudo-first-order, pseudo-second-order, and the intra-particle diffusion model's feasibility. The criterion for choosing the more feasible model was that it should be a good fit between the model and the experimental data. The best-fit model was determined by carrying out linear regressions of the linearized kinetic equation. The values analysis allowed the models' evaluation; below a short overview of the feasible models describing the adsorption kinetic data.

Lagergren proposed the empirical pseudo-first-order model (PFOM) [28]. The PFOM assumes that the absorption could be described by Equation (9). Solving Equation (9) with the boundary condition $q_{t=0}=0$, one obtains Equation (10). Equations (10) and (11) describe the nonlinear and linear forms of the PFOM.

$$
\begin{gathered}
\frac{d q_{t}}{d t}=k_{1}\left(q_{e}-q_{t}\right) \\
q_{t}=q_{e}\left(1-e^{-k_{1} t}\right) \text { when } q_{t=0}=0 \\
\ln \left(q_{e}-q_{t}\right)=\ln q_{e}-k_{1} t \text { when } q_{e}>q_{t}
\end{gathered}
$$

The values of $q_{e}$ and $k_{1}$ parameters are usually determined by applying the commonly accepted linear regression procedure, based on Equation (11). Where $q_{e}(\mathrm{mg} / \mathrm{g})$ and $q_{t}(\mathrm{mg} / \mathrm{g})$ are the amounts of adsorbate adsorbed at equilibrium and at any $t(\mathrm{~min})$, respectively. The $k_{1}\left(\min ^{-1}\right)$ represents the rate constant of the PFOM. Near to the equilibrium $q_{t} \rightarrow q_{e}$, the validation of the PFOM by Equation (11) is significative, affected by random data uncertainty $[23,29]$ Alternatively, the PFOM validation could be performed with its nonlinear forms in Equation (10).

The pseudo-second-order model (PSOM) proposed by Blanchard et al. [30] assumes that the adsorption follows second-order chemisorption (Equation (12)) [31]. PSOM has been used to describe chemisorption and ion exchange adsorption mechanisms [32]. Equation (13) describes the nonlinear and linear forms of the PSOM. By plotting $q_{t} / t$ 
vs. $q_{t}$, both $k_{2}$ and $q_{e}$ constant can be obtained. Furthermore, the initial adsorption rate $\left(h_{0} ; \mathrm{mg} / \mathrm{g} \times \mathrm{min}\right)$ can be determined using the relation $h_{o}=k_{2} q_{e}^{2}$.

$$
\begin{gathered}
\frac{d q_{t}}{d t}=k_{2}\left(q_{e}-q_{t}\right)^{2} \\
q_{t}=\frac{k_{2} q_{e}^{2} t}{1+k_{2} q_{e} t} \text { and } \frac{q_{t}}{t}=-\left(k_{2} q_{e}\right) q_{t}+k_{2} q_{e}^{2}
\end{gathered}
$$

where $q_{e}(\mathrm{mg} / \mathrm{g})$ and $q_{t}(\mathrm{mg} / \mathrm{g})$ are the amounts of adsorbate adsorbed at equilibrium and at any $t(\mathrm{~min})$, respectively. The $k_{2}(\mathrm{~g} / \mathrm{mg} \times \mathrm{min})$ represents the rate constant of the PSOM. The $t(\mathrm{~min})$ is the label for the contact time between the adsorbate and the adsorbent. Although the PSOM can adequately describe adsorption kinetic experimental data, this model does not help to reveal the adsorption mechanism.

The intra-particle diffusion model (IPDM) can help identify the reaction pathways and adsorption mechanisms and predicting the rate-controlling step [23]. Equation (14) shows the linearized transformation of the IPDM proposed by Weber and Morris [33]. In Equation (14) $K_{i p d}\left(\mathrm{mg} / \mathrm{g} \mathrm{min}^{\frac{1}{2}}\right)$ represents the rate constant of the IPDM and $C(\mathrm{mg} / \mathrm{g})$ is a constant associated with the boundary layer thickness. A higher value of $C$ corresponds to a more significant effect on the limiting boundary layer. By plotting $q_{t}$ vs. $\sqrt{t}$, both $K_{i p d}$ and $C$ constants can be obtained. If $C^{\prime}$ s value is equal to zero, the adsorption process is controlled by intra-particle diffusion.

$$
q_{t}=K_{i p d} \sqrt{t}+C
$$

\section{Results and Discussion}

\subsection{SEM and EDS Analysis}

The RC micrograph (Figure 1a) shows irregular structures of small size and a preferential laminar structure typical of clay samples. The agglomeration of the small particles forms clusters of different sizes. Also, it is possible to observe big single particles that suggest other mineral phases different from clay phases. The EDS spectra of the rectangle covering the whole image is shown in Figure $1 \mathrm{~b}$. The quantitative analysis of the spectra is shown in Figure 1c. Thus, the EDS analysis suggests the $\mathrm{Si}, \mathrm{Al}$, and $\mathrm{Fe}$ as the main constituent. These results are in agreement with clay samples, mainly constituted of aluminosilicate.

(a)

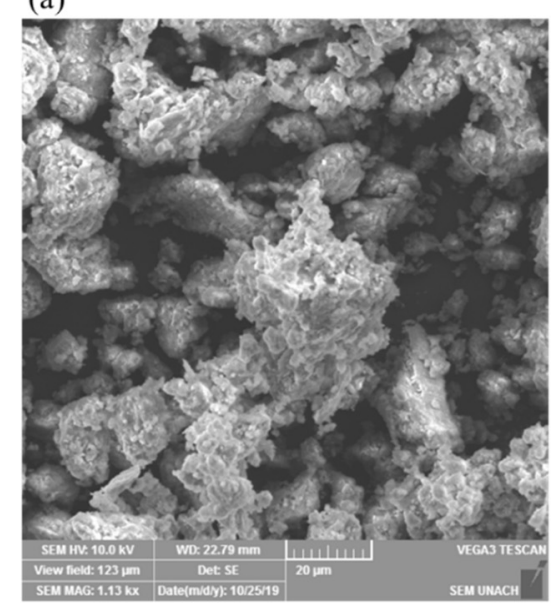

(b)

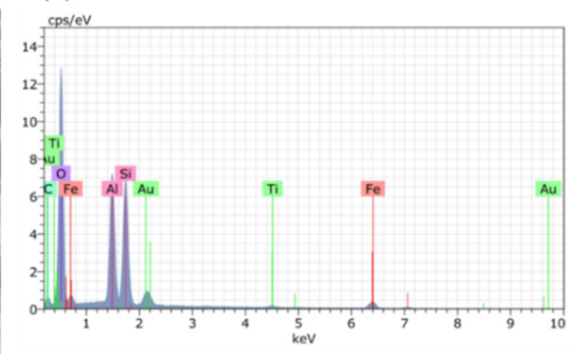

(c)

Figure 1. (a) Red clay micrograph. (b) Energy-dispersive spectroscopy of X-ray photon of the total micrograph area. (c) Elemental composition. 


\subsection{X-ray-Diffraction Analysis}

The RC sample's diffractograms are presented in Figure 2, in which several of the most intense peaks are pointed. The XRD semiquantitative analysis reveals that the RC sample contained a mixture of kaolinite (48.6\%); magnesiochloritoid $(22.4 \%)$; $\mathrm{Na}$, K-rich laumontite $(23.3 \%)$; and hematite $(5.8 \%)$ (Table 2$)$. Thus, the RC's constituents are mineral clays and associated minerals.

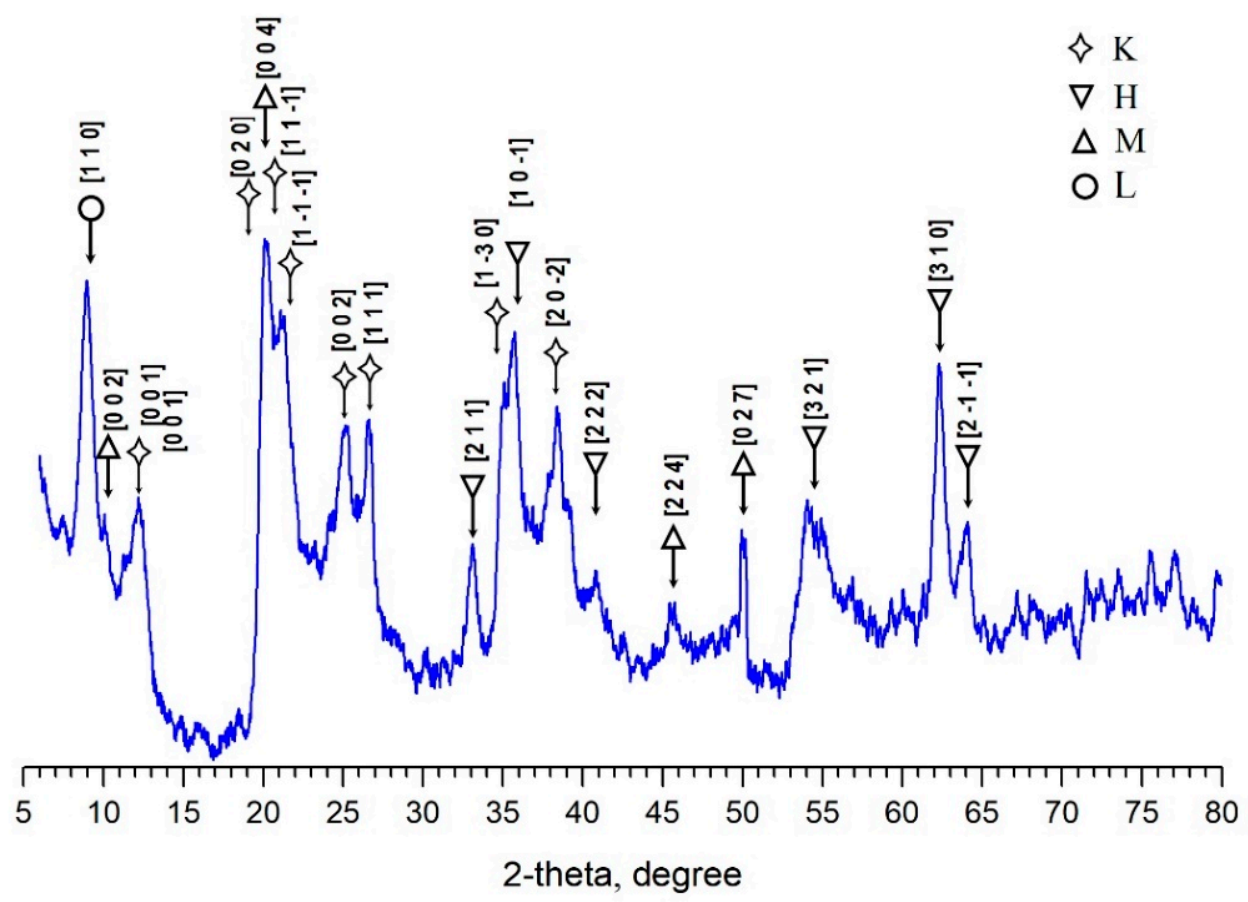

Figure 2. Diffractogram of the red clay sample. Kaolinite (K); hematite (H); magnesiochloritoid (M); and $\mathrm{Na}$, K-rich laumontite (L).

Table 2. The red clay diffractogram qualitative analysis.

\begin{tabular}{cccc}
\hline Card & Compound & Chemical Formula & wt \% \\
\hline $00-155-0598$ & Kaolinite & $\mathrm{Al}_{2} \mathrm{H}_{4} \mathrm{O}_{9} \mathrm{Si}_{2}$ & 48.6 \\
$00-900-6106$ & Magnesiochloritoid & $\mathrm{Al}_{2} \mathrm{Fe}_{0.35} \mathrm{H}_{2} \mathrm{Mg}_{0.65} \mathrm{O}_{7} \mathrm{Si}$ & 22.4 \\
$00-154-8100$ & $\mathrm{Na}$, K-rich laumontite & $\mathrm{Al}_{2} \mathrm{Ca}_{0.68} \mathrm{~K}_{0.26} \mathrm{Na}_{0.36} \mathrm{O}_{15.63} \mathrm{Si}_{4}$ & 23.3 \\
$00-900-9782$ & Hematite & $\alpha-\mathrm{Fe}_{2} \mathrm{O}_{3}$ & 5.8 \\
\hline
\end{tabular}

\subsection{Vis-NIR Analysis}

As the energy quantum is directly related to photon frequency $(v)$ and inversely related to its wavelength $(\lambda)$, the resulting absorption spectrum exhibits characteristic shapes useful for analytical purposes. The photon wavelength at which radiation is absorbed appears as a reduced signal of reflected radiation and is displayed in \% reflectance $(R)$, which can then be transformed to apparent absorbance: $A=\log (1 / R)$. The wavelength at which the absorption occurs (i.e., the energy quantum size) also depends on the chemical matrix and environmental factors such as neighboring functional groups and temperature. This wavelength allows the detection of a range of molecules that contain the same type of bonds [34].

The RC's DR spectrum (Figure 3) shows variations in the absorbance, a wavelength associated with functional groups of iron oxides, water, hydroxyl, and clay minerals (Table 3). Iron oxides are spectrally active across the Vis-NIR region based on the electronic transition of iron cations $\mathrm{Fe}^{3+}, \mathrm{Fe}^{2+}$, as summarized by Pearlshtien and Ben-Dor [35]. The RC's DR spectrum displays the steep red slope between the $400 \mathrm{~nm}$ and $700 \mathrm{~nm}$ 
characteristic of $\mathrm{Fe}^{3+}$. A broad minimum is around $650 \mathrm{~nm}$ and $884 \mathrm{~nm}$ attributable to iron oxide minerals such as hematite (Table 3). Clay-sized hematite crystals can arise as a secondary mineral formed by weathering processes in soil. Thus, it would be responsible for the reddish color found in the RC samples. In contrast, samples with goethite would show a yellowish-brown color [7,35-38].

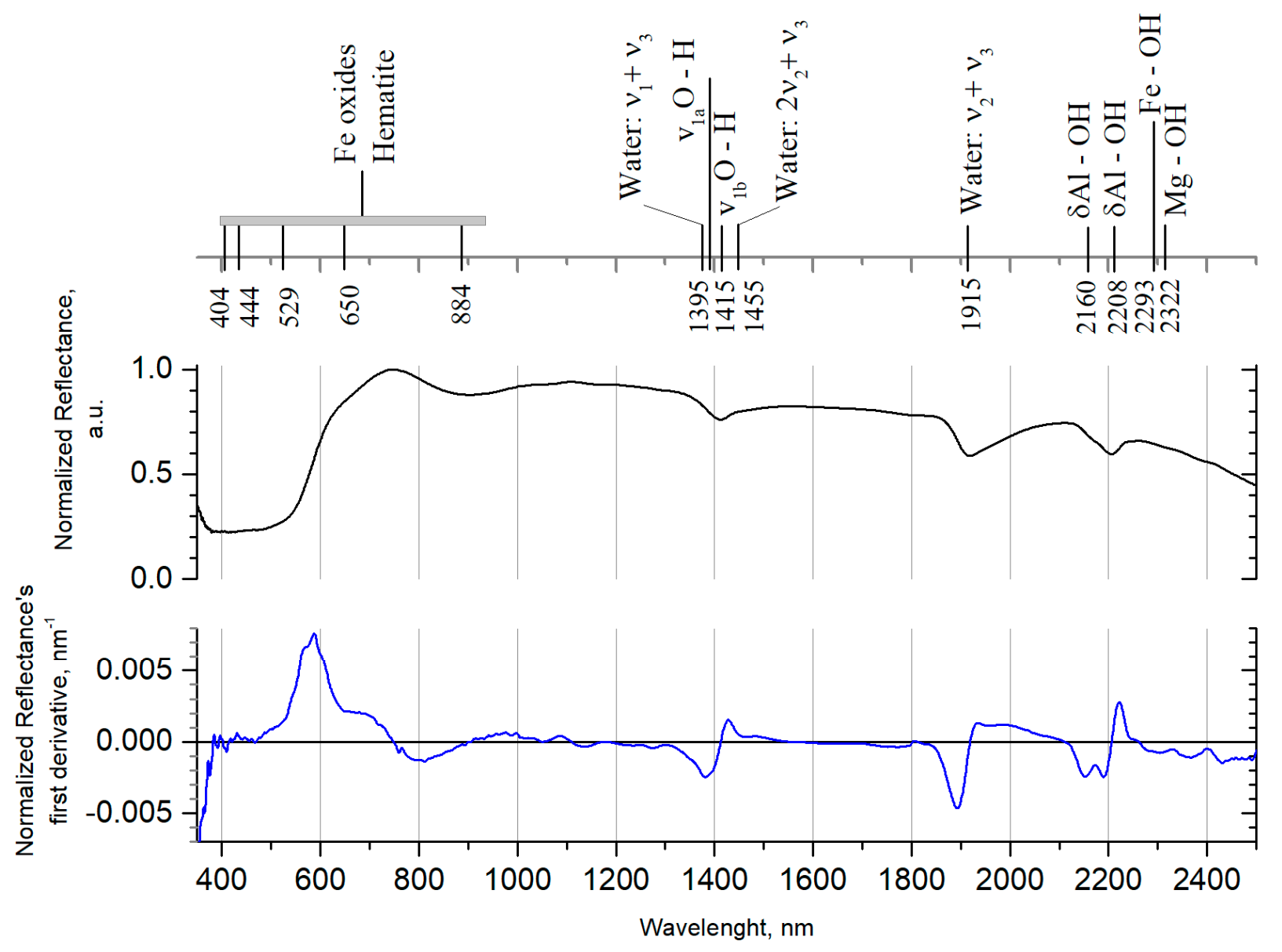

Figure 3. The red clay diffuse reflectance spectrum and its first derivative.

The minima around $1400 \mathrm{~nm}$ and $1900 \mathrm{~nm}$ are commonly associated with tones and overtones of $\mathrm{H}_{2} \mathrm{O}$ and $\mathrm{OH}-$ (Table 3) [38]. The RC's DR spectrum displays one or more small minima between around 2150 and $2400 \mathrm{~nm}$. These minima would be due to Si$\mathrm{OH}$ and cation-OH bonds in phyllosilicate minerals (e.g., kaolinite) [37,38]. Previous investigations confirm the kaolin doublet's observation around $1400 \mathrm{~nm}$ and $2200 \mathrm{~nm}$ (Figure 3 and Table 3), corresponding to the $-\mathrm{OH}$ stretch vibration of water in the crystal lattice of silicates and Al-OH bending modes [39]. The minimum around 2310-2330 nm could be assigned to magnesiochloritoid [40,41]. The RC's DR spectrum shows features associated with functional groups of Fe oxides (hematite), water, hydroxyl, kaolinite, and magnesiochloritoid. Therefore, untreated red clay's characterization suggests a clayey composite mainly constituted by a mineral clay (kaolinite), laumontite, and secondary minerals (iron-containing particles). 
Table 3. Band assignments for fundamental mid-IR absorption of red clay constituents and their overtone and combinations in the Vis-NIR [38,40-42]. For the sake of simplicity, some selected wavelengths were not represented in Figure 3.

\begin{tabular}{|c|c|c|c|}
\hline Sample Constituent & Fundamental, $\mathrm{cm}^{-1}$ & $\begin{array}{c}\text { Vis-NIR } \\
\text { Wavelength, nm }\end{array}$ & Vis-NIR Mode \\
\hline Fe oxides (Hematite) & & $404,444,529650,884$ & Electronic transitions \\
\hline \multirow{5}{*}{ Water } & $v_{1}:$ O-H: $3278 \mathrm{~cm}^{-1}$ & 1915 & $v_{1}+v_{2}$ \\
\hline & $v_{2}:$ O-H: $1645 \mathrm{~cm}^{-1}$ & 1455 & $2 v_{2}+v_{3}$ \\
\hline & $v_{3}:$ O-H: $3484 \mathrm{~cm}^{-1}$ & 1380 & $v_{1}+v_{3}$ \\
\hline & & 1135 & $v_{1}+v_{2}+v_{3}$ \\
\hline & & 940 & $2 v_{1}+v_{3}$ \\
\hline \multirow{3}{*}{ Hydroxyl } & & 1400 & $2 v_{1}$ \\
\hline & $v_{1}:$ O-H: $3575 \mathrm{~cm}^{-1}$ & 930 & $3 v_{1}$ \\
\hline & & 700 & $4 v_{1}$ \\
\hline \multirow{6}{*}{ Kaolin doublet } & $v_{1 \mathrm{a}}: \mathrm{O}-\mathrm{H}: 3695 \mathrm{~cm}^{-1}$ & 1395 & $2 v_{1 \mathrm{a}}$ \\
\hline & $v_{1 \mathrm{~b}}: \mathrm{O}-\mathrm{H}: 3620 \mathrm{~cm}^{-1}$ & 1415 & $2 v_{1 b}$ \\
\hline & $\delta: \mathrm{O}-\mathrm{H}: 915 \mathrm{~cm}^{-1}$ & 2160 & $2 v_{1 a}+\delta$ \\
\hline & & 2208 & $2 v_{1 b}+\delta$ \\
\hline & v: Fe-H: $3508 \mathrm{~cm}^{-1}$ & 1425 & $2 v$ \\
\hline & $\delta: \mathrm{Fe}-\mathrm{OH}: 853 \mathrm{~cm}^{-1}$ & 2293 & $v+\delta[43]$ \\
\hline Magnesiochloritoid & $\delta: \mathrm{Mg}-\mathrm{OH}: 1090 \mathrm{~cm}^{-1}$ & 2322 & $\mathrm{v}+\delta[42,43]$ \\
\hline
\end{tabular}

\subsection{Solution $p H$ Effect}

The CNB dye removal was higher than $96 \%$ at a low $\mathrm{pH}$ and decreased around $75 \%$ in a solution at $\mathrm{pH}$ higher than 8 (Figure 4a). However, ADY removal was around 90\% at a low $\mathrm{pH}$ and decreased to lower than $30 \%$ at a pH higher than 8 (Figure $4 \mathrm{~b}$ ). The RC particles are charged positively. Similar charges on the CNB and the RC's surface cause repulsion between the CNB and the RC. However, results in Figure 4a suggest that the CNB participates in breaking and making bonds. These interactions are described as inner-sphere complexes due to CNB's and the surface's ability to reach each other, enabling the orbitals' overlapping responsible for the bonding. Jagadamma [44] concluded that this bonding process is significant when the inorganic surface exposes metals like iron or aluminum to utilize organic adsorbate as one of the ligands. This result agrees that the $\mathrm{RC}$ sample is a mixture of kaolinite clay particles (KPs); $\mathrm{Na}$, K-rich laumontite particles (LPs), and iron-containing particles (IPs). We hypothesize that the IPs expose iron on their surfaces, which forms covalent bonds with the CNB dye molecules, and show affinity by the CNB molecules.

In a high-pH solution, the CNB removal decreases to around 75\% (Figure 4a). The RC particles are charged negatively. The $\mathrm{OH}^{-}$neutralizes the CNB. Opposite charges on KPs and $\mathrm{CNB}$ dye molecules cause the emergence of electrostatic attraction between CNB and KPs. Nevertheless, the result suggests no affinity between the $\mathrm{CNB}$ and the IPs at high $\mathrm{pH}$. Thus, the removal of $\mathrm{CNB}$ molecules at a high $\mathrm{pH}$ decreases. Therefore, the results suggest that in a low-pH solution, the mechanism of $\mathrm{CNB}$ removal could be due to chemisorption. At high $\mathrm{pH}$, the removal mechanism could be due to physisorption.

The adsorption mechanism can be broadly divided into three categories: physisorption, chemisorption, and ion exchange [45]. The physisorption mechanism refers to surface adsorption without disrupting the adsorbent's electronic orbitals and adsorbate. It could involve van der Waals interactions, electrostatic interactions, hydrogen bonding, diffusion, and hydrophobic interaction ( $\pi-\pi$ interaction and Yoshida interaction [46]. Physisorption is a reversible and exothermal phenomenon [47]. In contrast, the chemisorption mechanism involves electronic orbital and valence forces between absorbent and adsorbate. It generates a chemical bond to the surface of the adsorbent and is irreversible. The mechanism of the chemisorption process can involve complex formation, chelation, covalent bonding, redox 
reaction, and proton displacement. As a consequence of chemisorption, the electronic state of adsorbent changes, and it can be observed using, for example, FTIR, Raman, XPS, magnetic susceptibility, among other techniques [45]. Therefore, more studies need to be done to elucidate the adsorption mechanism of the CNB to low and high $\mathrm{pH}$.

(a)

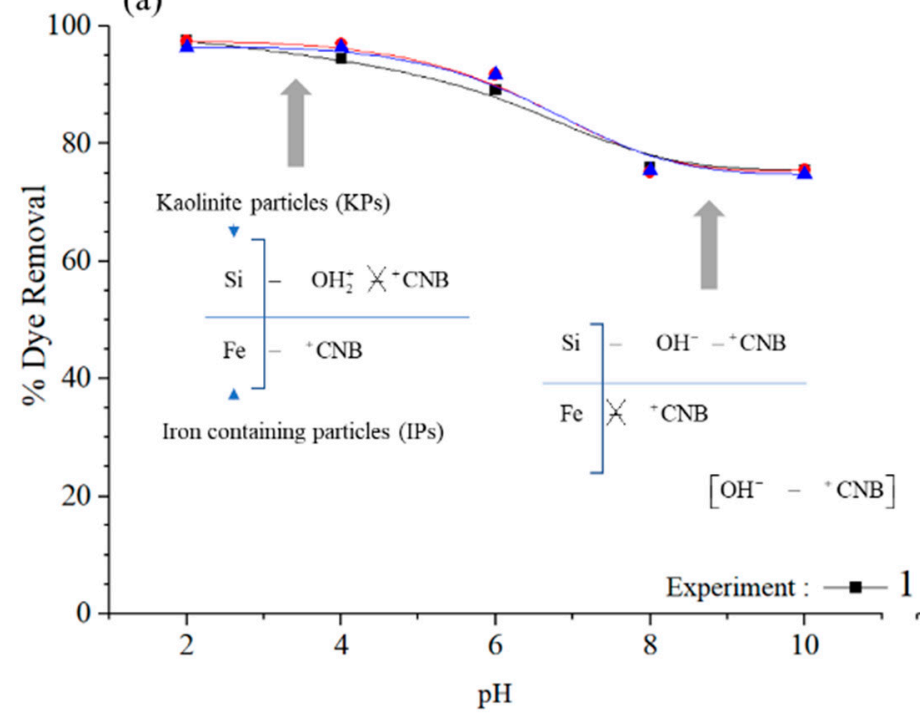

(b)

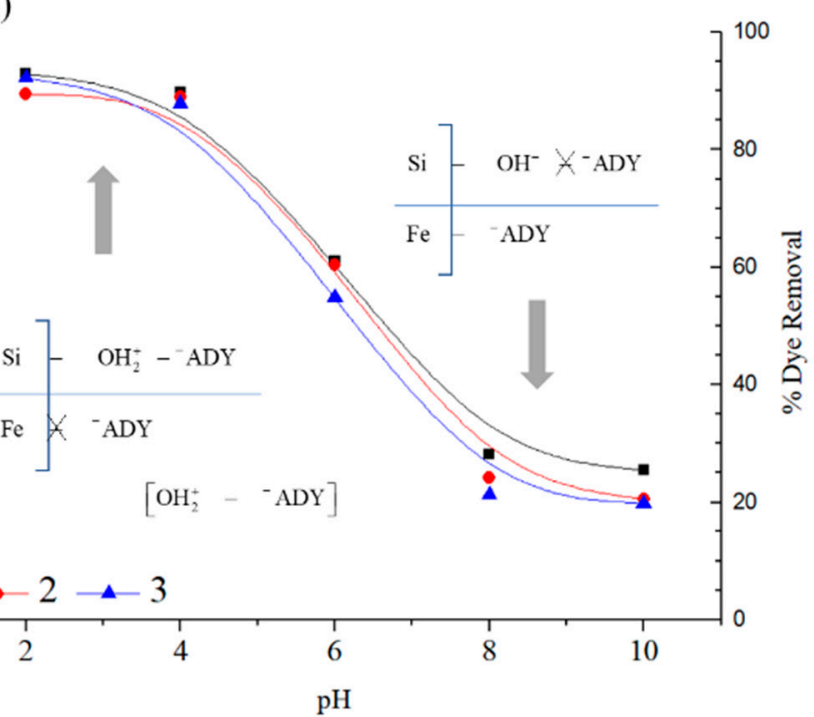

Figure 4. (a) Effect of $\mathrm{pH}$ on Basic Navy Blue 2RN (CNB) removal. (b) Effect of pH on Drimaren Yellow Cl-2R (ADY) removal. Adsorbate concentration $50 \mathrm{mg} / \mathrm{g}$. Adsorbent dose $0.5 \mathrm{~g} / 50 \mathrm{~mL}$.

In solution at low $\mathrm{pH}$, the KPs are charged negatively (Figure $4 \mathrm{~b}$ ). The ion $\mathrm{OH}_{2}^{+}$ neutralizes the ADY dye in the solution. However, the high ADY dye removal at a low $\mathrm{pH}$ could be due to the emergence of electrostatic attraction between ADY and KPs due to the opposite charges on KPs and ADY dye molecules. Nevertheless, the result suggests no affinity between the ADY and the IPs at a low $\mathrm{pH}$. Thus, the ADY's high removal at a low $\mathrm{pH}$ is mainly due to ADT dye molecules' physisorption onto positively charged KPs. There is no electrostatic interaction between the negatively charged KPs and the ADY in solution at a high $\mathrm{pH}$. We hypothesize a slight affinity between the ADY and the IPs because the removal decreases to around $20 \%$. Therefore, in a solution at low $\mathrm{pH}$, the mechanism of ADY removal is through physisorption. In contrast, the removal mechanism is at high $\mathrm{pH}$ through "incipient" chemisorption due to a low affinity between the ADY dye and the IPs (Figure 4b).

\subsection{Dye Concentration Effect}

When the initial dye concentration increases from 10 to $60 \mathrm{mg} / \mathrm{L}$, the adsorption capacity rises from 0.7 to $5.2 \mathrm{mg} / \mathrm{g}$ and 0.8 to $5.7 \mathrm{mg} / \mathrm{g}$ for CNB and ADY dye, respectively (Figure 5). The amount of absorbent remains constant and equal to $0.5 \mathrm{~g}$ of RC in $50 \mathrm{~mL}$ of solution. Figure 5 shows a linear dependency between the amount of adsorbate adsorbed and the initial dye concentration. From Equation (2), we have $\partial q_{e} / \partial C_{0}=k\left(1-\partial C_{e} / \partial C_{0}\right)$ where $k \equiv V / m_{c}$, and $\partial C_{e} / \partial C_{0}=(1-m / k)$ where $m \equiv \partial q_{e} / \partial C_{0}$. Therefore, we have a framework helpful in studying the dye concentration effect (Table 4). 

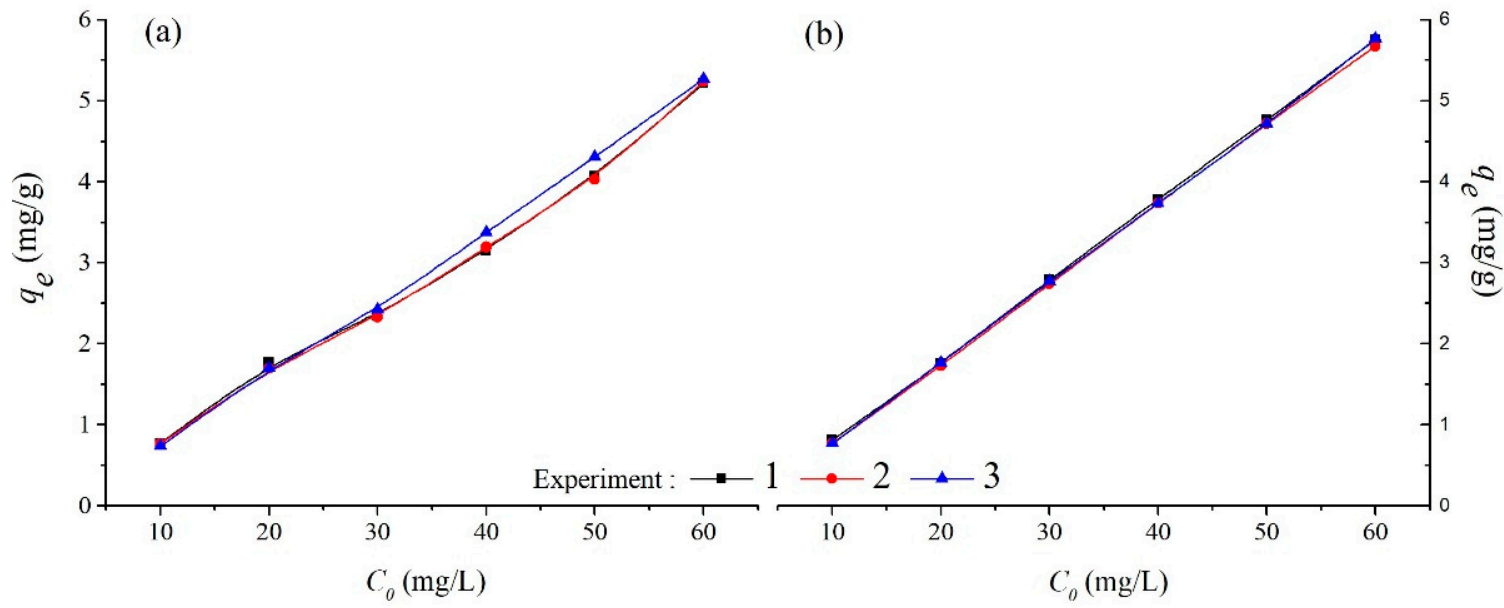

Figure 5. (a) Effect of the initial Basic Navy Blue 2RN (CNB)concentration on adsorption capacity. (b) Effect of the initial Drimaren Yellow Cl-2R (ADY) concentration on adsorption capacity. Adsorbent dose $0.5 \mathrm{~g} / 50 \mathrm{~mL} . \mathrm{pH}(\mathrm{cationic})=6$, $\mathrm{pH}$ (anionic) $=2$.

Table 4. Framework for the study of the dye concentration effect on the amount of adsorbate absorbed.

\begin{tabular}{|c|c|c|c|}
\hline$m$ & $\partial q_{e} / \partial C_{0}$ & $\partial C_{e} / \partial C_{0}$ & Comment \\
\hline$=0$ & $\begin{array}{l}=0 \text {, An increase in Co implies that there } \\
\text { is no change in the amount of adsorbate } \\
\text { adsorbed. }\end{array}$ & $\begin{array}{c}=1, \text { An increase in Co implies } \\
\text { an equal increase in } C e .\end{array}$ & Upon saturation \\
\hline$<\mathrm{k}$ & $\begin{array}{l}<\mathrm{k}, \text { A change in Co implies a } \\
\text { proportional and minor change in the } \\
\text { amount of adsorbate adsorbed. }\end{array}$ & $\begin{array}{c}>0, \text { An increase in Co implies } \\
\text { an increase in } \mathrm{Ce} .\end{array}$ & Adsorbing \\
\hline$=\mathrm{k}$ & $\begin{array}{l}=\mathrm{k}, \text { A change in Co implies a } \\
\text { proportional and equal change in the } \\
\text { amount of adsorbate adsorbed. }\end{array}$ & $\begin{array}{l}=0, \text { An increase in Co implies } \\
\text { that there is no change in } \mathrm{Ce} \text {. }\end{array}$ & Full adsorption \\
\hline$>\mathrm{k}$ & $\begin{array}{l}>\mathrm{k}, \mathrm{A} \text { change in Co implies a } \\
\text { proportional and higher change in the } \\
\text { amount of adsorbate adsorbed. }\end{array}$ & $\begin{array}{c}<0 \text {, An increase in Co implies a } \\
\text { decrease in Ce. }\end{array}$ & Unlikely \\
\hline
\end{tabular}

For data in Figure 5, the $k$ value was equal to 0.100, and the $m$ value was equal to 0.090 and 0.098 for CNB and ADY, respectively. Hence $m<k$, the system does not reach the complete adsorption condition $(m=k)$ (Table 4$)$. The full adsorption condition occurs when all the initial dye amount is completely adsorbed. Assuming that the value $m=V / m_{c}$ will remain constant, the complete adsorption condition would be reached if the amount of adsorbent is equal to $0.555 \mathrm{~g} / 50 \mathrm{~mL}$ and $0.510 \mathrm{~g} / 50 \mathrm{~mL}$ for the $\mathrm{CNB}$ and $\mathrm{ADY}$, respectively. We recall our hypothesis that $\mathrm{CNB}$ is mainly removed by chemisorption on IPs. The ADY is removed mainly by physisorption on the KPs and LPs.

Umoren et al. [48], Anirudhan and Ramachandran [49], and Yu et al. [50] reported that dye removal should decreases at higher dye concentrations, as the adsorbent's active sites become saturated. Oluwafemi and Ojo [51] reported that decreased dye removal could be due to an unchanged adsorption capacity. Nevertheless, the CNB and ADY dye removal increased as the dye concentration increased (Figure 6). From 10 to 60, the removal increases from $77 \%$ to $87 \%$ and $77 \%$ to $95 \%$ for CNB and ADY dyes, respectively (Figure 6).

The results in Figure 6 are in agreement with the explanation given to the information in Figure 5. In both systems, the experimental amount of absorbent is equal to $0.500 \mathrm{~g} / 50 \mathrm{~mL}$ (Figure 6). However, the values of adsorbent for complete adsorption should be $0.550 \mathrm{~g} / 50 \mathrm{~mL}$ and $0.510 \mathrm{~g} / 50 \mathrm{~mL}$ for the CNB and ADY dye, respectively. Thus, the CNB system was working further from the complete adsorption condition, and dye 
removal was smaller than the ADY that was working closer to the complete adsorption condition. We recall that the postulated mechanism for $\mathrm{CNB}$ adsorption is chemisorption.

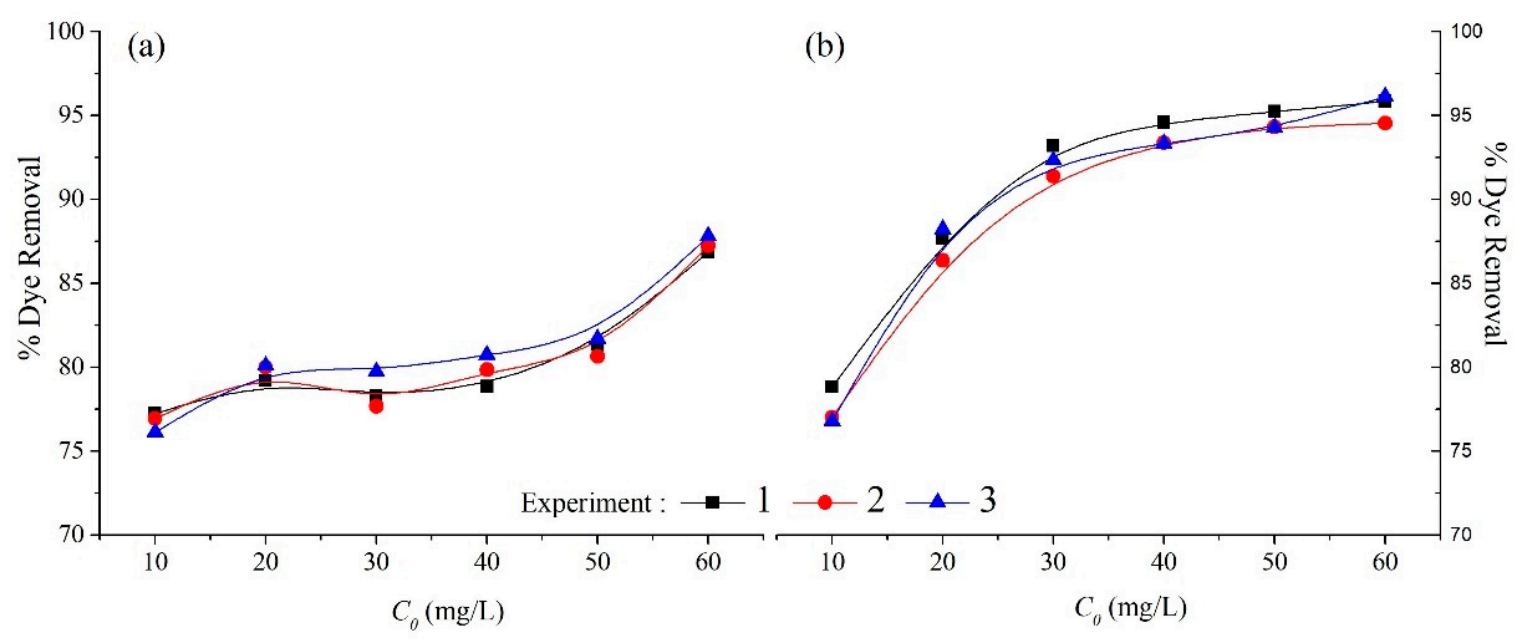

Figure 6. (a) Effect of initial Basic Navy Blue 2RN (CNB) dye concentration on dye removal. (b) Effect of the initial Drimaren Yellow Cl-2R (ADY) dye concentration on dye removal. Adsorbent dose $0.5 \mathrm{~g} / 50 \mathrm{~mL}$. pH (cationic) $=6, \mathrm{pH}($ anionic) $=2$.

Moreover, $\mathrm{CNB}$ removal depends on how easily the $\mathrm{CNB}$ molecules get closer to the IPs. At high CNB dye concentration, the CNB molecule gets closer to the IPs, and the removal should increase. Thus, the ADY dye removal is higher than the CNB dye removal by ADY's physisorption onto KPs and LPs. In agreement with our hypothesis, CNB removal proceeds by forming a chemisorbed monolayer on the IPs. The ADY removal proceeds by forming a physisorbed monolayer of ADY onto KPs.

\subsection{Adsorbent Amount Effect}

While the absorbent amount increases from 0.2 to $1.2 \mathrm{~g} / 50 \mathrm{~mL}$ and the absorbate concentration is $50 \mathrm{mg} / \mathrm{L}$, the CNB and ADY dye removal increases from $78 \%$ to $97 \%$ and from $87 \%$ to $97 \%$, respectively (Figure 7). Several authors reported that dye removal is proportional to the adsorbent amount $[16,49,52]$. The ADY adsorption quickly progresses closer to the complete adsorption. The CNB adsorption slowly progresses closer to the complete adsorption. Thus, ADY removal demands a smaller amount of RC particles.
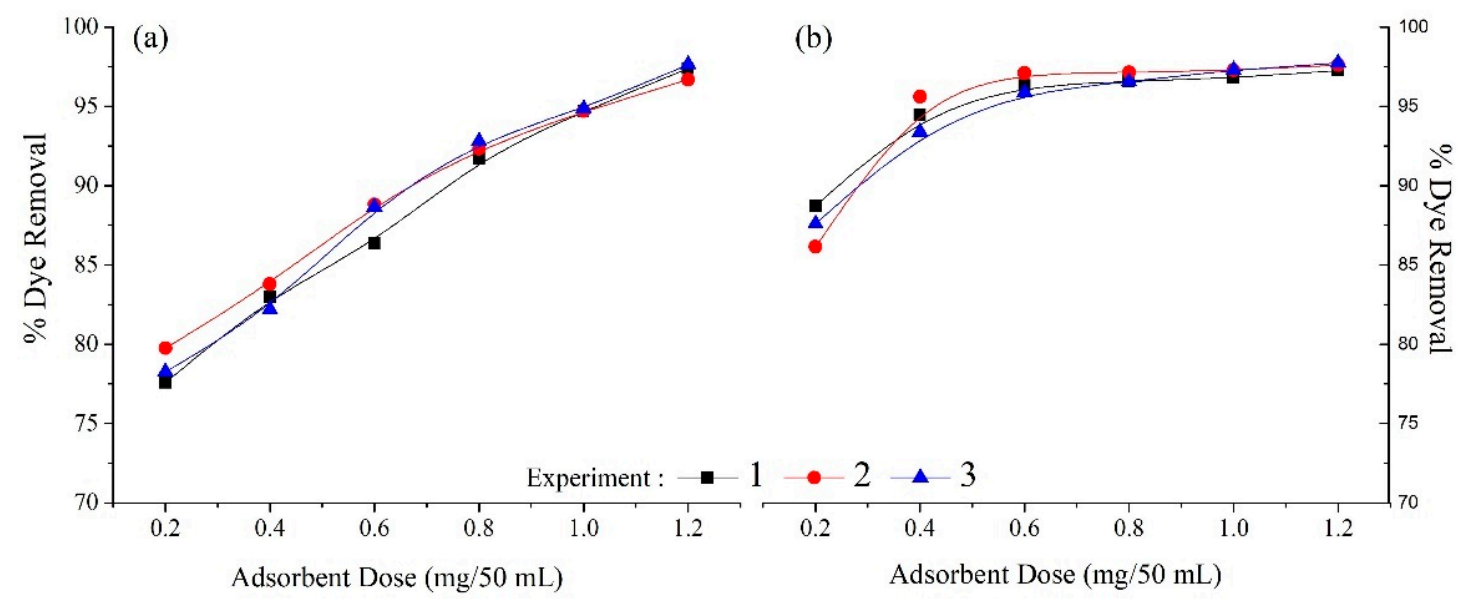

Figure 7. (a) Effect of adsorbent dosage on Basic Navy Blue 2RN dye removal. (b) Effect of adsorbent dosage on Drimaren Yellow CL-2R dye removal. Adsorbate concentration $50 \mathrm{mg} / \mathrm{L}$. $\mathrm{pH}$ (cationic) =6, pH (anionic) $=2$. 
In contrast, the CNB dye's remotion demands more RC particles. However, following the above-proposed model, the differences in RC particle amounts strongly depend on the IPs' and KPs' proportions in the RC's total amount. The results in Figure 7 support the proposed adsorption models. With an increment in the adsorbent dose in the CNB adsorption system, the number of active absorption sites increases for more molecules' chemisorption on the IPs' surfaces [18].

Figure 8 shows that the amount of dye adsorbed at equilibrium (adsorption capacity) decreases from $9.6 \mathrm{mg} / \mathrm{g}$ to $2.0 \mathrm{mg} / \mathrm{g}$ for the CNB dye. From $10.9 \mathrm{mg} / \mathrm{g}$ to $2.0 \mathrm{mg} / \mathrm{g}$ for ADY dye as the adsorbent amount increases. The initial adsorbate concentration is $50 \mathrm{mg} / \mathrm{g}$. If the adsorbent amount increases, there are more available sites for adsorption. As the adsorbate amount remains constant, then each RC particle gets fewer adsorbed dye molecules. The authors of $[16,53,54]$ reported a similar trend.

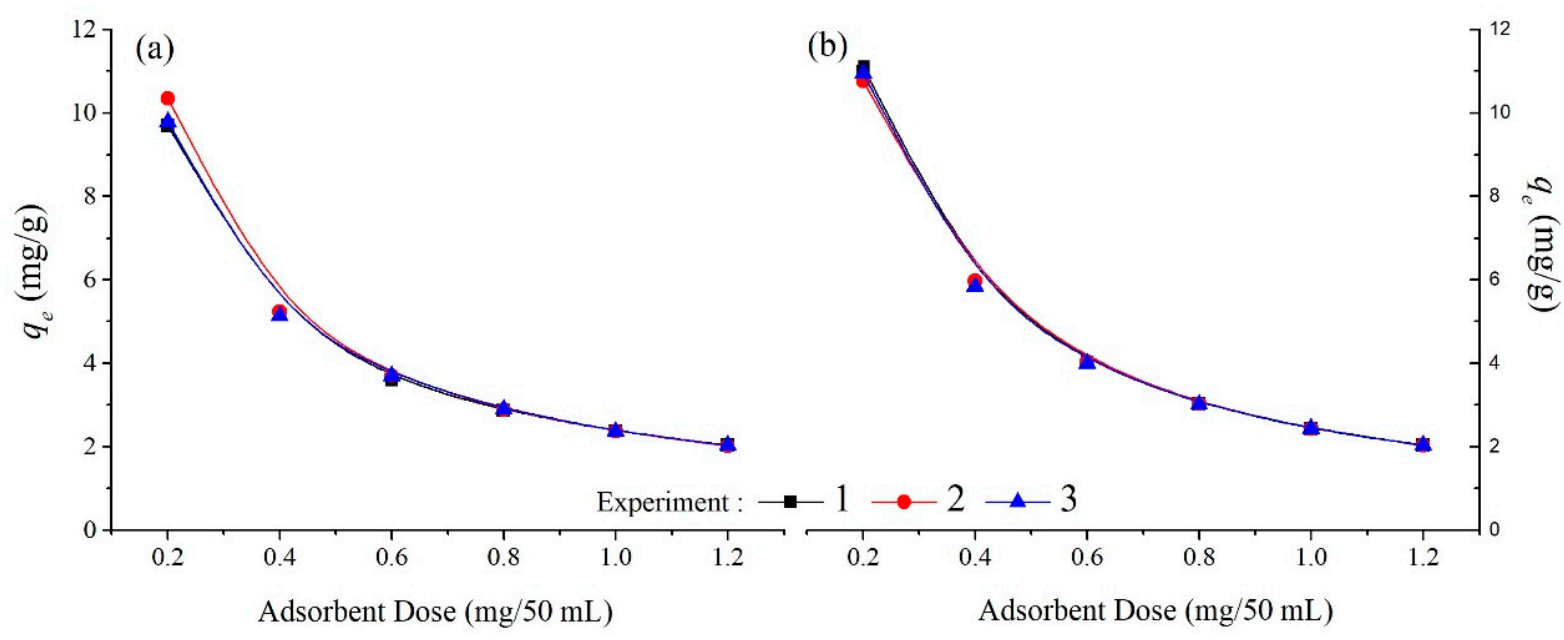

Figure 8. Effect of adsorbent dosage on adsorption capacity of (a) Basic Navy Blue 2RN and (b) Drimaren Yellow CL-2R. Adsorbate concentration $50 \mathrm{mg} / \mathrm{L} . \mathrm{pH}$ (cationic) $=6, \mathrm{pH}$ (anionic) $=2$.

\subsection{Adsorption Isotherms}

The results of fitting the Langmuir, Freundlich, Tempkin, and Dubinin-Radushkevich isotherms models to the CNB adsorption data are shown in Table 5. The Langmuir isotherm model fits very well with CNB experimental data $\left(R^{2}>0.96\right.$ in all adsorption experiments). This result supports the hypothesis that $\mathrm{CNB}$ removal proceeds by forming a chemisorbed monolayer on IPs. Thus, this result is in agreement with the chemisorption mechanism proposed above. The maximum monolayer adsorption capacities were $10.614,6.146$, and $6.013 \mathrm{mg} / \mathrm{g}$ for $0.25,0.50$, and $0.75 \mathrm{~g} / 50 \mathrm{~mL}$ of adsorbent, respectively. The $R_{L}$ values are less than 1. It agrees with the CNB molecules' favorable adsorption by the IPs [55].

The TM model shows the best fit between the isotherm function and the ADY dyeadsorption data (Table 6). The $\mathrm{R}^{2}$ values were $0.913,0.906$, and 0.670 for $0.25 \mathrm{~g} / 50 \mathrm{~mL}$, $0.50 \mathrm{~g} / 50 \mathrm{~mL}$, and $0.75 \mathrm{~g} / 50 \mathrm{~mL}$ of $\mathrm{RC}$, respectively. This result agrees with the suggested mechanism for ADY removal by monolayer formation throughout ADY physisorption on KPs. However, the TM considers the interaction between the absorbent and the absorbate while ignoring large and low concentrations. Thus, the TM is valid for an intermediate concentration range [22]. The low $\mathrm{R}^{2}$ values at 0.75 for the TM suggest that the TM becomes less suitable for experimental data representation. The system is becoming more complex. Numerous factors, including the $\mathrm{pH}$, temperature, and surface chemistry of the absorbent, among others, can influence the ADY adsorption. Since the complex phenomenon involved in liquid-phase adsorption is not considered by this equation [56], the DRM is not necessarily significantly worse than TM (Table 6). However, the results suggest that the TM is statistically more suitable to describe the isotherms' adsorption 
of the ADY dye onto the clayed subtract. However, both models lead to low adsorption energy that suggests physic adsorption.

Table 5. Characteristic parameters of the adsorption isotherms model after it was fitted with the experimental data obtained with the CNB-Basic 2RN Navy Blue Dye. Adsorbate concentration $50 \mathrm{mg} / \mathrm{L} . \mathrm{pH}=6$.

\begin{tabular}{|c|c|c|c|c|}
\hline \multirow{2}{*}{ Isothermal } & \multirow{2}{*}{ Parameter } & \multicolumn{3}{|c|}{ Adsorbent (g/50 mL) } \\
\hline & & 0.25 & 0.50 & 0.75 \\
\hline \multirow{4}{*}{ Langmuir } & $q_{m}[\mathrm{mg} / \mathrm{g}]$ & $10.614 \pm 2.354$ & $6.146 \pm 0.693$ & $6.013 \pm 1.747$ \\
\hline & $K_{L}[\mathrm{~L} / \mathrm{mg}]$ & $0.290 \pm 0.084$ & $0.511 \pm 0.036$ & $0.390 \pm 0.165$ \\
\hline & $R^{2}$ & 0.963 & 0.991 & 0.991 \\
\hline & $R_{L}$ & $0.187 \pm 0.005$ & $0.103 \pm 0.070$ & $0.178 \pm 0.110$ \\
\hline \multirow{3}{*}{ Freundlich } & $K_{F}\left[(\mathrm{mg} / \mathrm{g}) /(\mathrm{mg} / \mathrm{L})^{n}\right]$ & $2.283 \pm 0.519$ & $1.906 \pm 0.053$ & $1.540 \pm 0.244$ \\
\hline & $n$ & $1.994 \pm 0.312$ & $2.156 \pm 0.052$ & $1.993 \pm 0.358$ \\
\hline & $R^{2}$ & 0.875 & 0.995 & 0.834 \\
\hline \multirow{4}{*}{ Temkin } & $\left(R T / b_{t}\right)[\mathrm{J} / \mathrm{mol}]$ & $2.842 \pm 0.840$ & $1.489 \pm 0.160$ & $1.176 \pm 0.130$ \\
\hline & $b_{T}$ & $863.494 \pm 362.310$ & $1647.649 \pm 198.301$ & $2086.756 \pm 259.348$ \\
\hline & $A_{T}[\mathrm{~L} / \mathrm{g}]$ & $1.582 \pm 0.149$ & $3.772 \pm 0.043$ & $4.188 \pm 0.008$ \\
\hline & $R^{2}$ & 0.718 & 0.955 & 0.946 \\
\hline \multirow{5}{*}{$\begin{array}{l}\text { Dubinin- } \\
\text { Radushkevich }\end{array}$} & $q_{m}[\mathrm{mg} / \mathrm{g}]$ & $7.838 \pm 1.650$ & $4.698 \pm 0.706$ & $3.889 \pm 0.452$ \\
\hline & $V \quad[\quad-2$ & $4.81 \times 10^{-7} \pm$ & $2.06 \times 10^{-7} \pm$ & $2.65 \times 10^{-7} \pm$ \\
\hline & $K_{D R}\left[\mathrm{~mol}^{2} / \mathrm{kJ}^{2}\right]$ & $1.93 \times 10^{-8}$ & $2.08 \times 10^{-8}$ & $4.10 \times 10^{-8}$ \\
\hline & $E[\mathrm{~kJ} / \mathrm{mol}]$ & $1.019 \pm 0.021$ & $1.558 \pm 0.072$ & $1.373 \pm 0.095$ \\
\hline & $R^{2}$ & 0.565 & 0.787 & 0.911 \\
\hline
\end{tabular}

Table 6. Characteristic parameters of the adsorption isotherms model after it was fitted with the experimental data obtained with the ADY-Drimaren Yellow Dye CL-2R. Adsorbate concentration $50 \mathrm{mg} / \mathrm{L} \cdot \mathrm{pH}=2$.

\begin{tabular}{|c|c|c|c|c|}
\hline \multirow{2}{*}{ Isothermal } & \multirow{2}{*}{ Constants } & \multicolumn{3}{|c|}{ Adsorbent (g/50 mL) } \\
\hline & & 0.25 & 0.50 & 0.75 \\
\hline \multirow{4}{*}{ Langmuir } & $q_{m}[\mathrm{mg} / \mathrm{g}]$ & $13.510 \pm 2.873$ & $1.311 \pm 0.718$ & $0.130 \pm 0.107$ \\
\hline & $K_{L}[\mathrm{~L} / \mathrm{mg}]$ & $0.113 \pm 0.092$ & $0.440 \pm 0.065$ & $0.394 \pm 0.016$ \\
\hline & $R^{2}$ & 0.595 & 0.695 & 0.625 \\
\hline & $R_{L}$ & $0.371 \pm 0.207$ & $0.137 \pm 0.084$ & $0.131 \pm 0.091$ \\
\hline \multirow{3}{*}{ Freundlich } & $K_{F}\left[(\mathrm{mg} / \mathrm{g}) /(\mathrm{mg} / \mathrm{L})^{n}\right]$ & $2.016 \pm 1.036$ & $0.877 \pm 0.755$ & $0.559 \pm 0.502$ \\
\hline & $n$ & $0.857 \pm 0.198$ & $0.335 \pm 0.016$ & $0.297 \pm 0.028$ \\
\hline & $R^{2}$ & 0.705 & 0.835 & 0.528 \\
\hline \multirow{4}{*}{ Temkin } & $\left(R T / b_{t}\right)[\mathrm{J} / \mathrm{mol}]$ & $8.609 \pm 1.310$ & $10.902 \pm 1.731$ & $8.760 \pm 4.802$ \\
\hline & $b_{T}$ & $285.062 \pm 51.636$ & $225.104 \pm 31.278$ & $280.145 \pm 43.163$ \\
\hline & $A_{T}[\mathrm{~L} / \mathrm{g}]$ & $0.885 \pm 0.053$ & $0.916 \pm 0.069$ & $0.894 \pm 0.185$ \\
\hline & $R^{2}$ & 0.913 & 0.906 & 0.670 \\
\hline \multirow{5}{*}{$\begin{array}{c}\text { Dubinin- } \\
\text { Radushkevich }\end{array}$} & $q_{m}[\mathrm{mg} / \mathrm{g}]$ & $18.519 \pm 4.054$ & $27.805 \pm 10.105$ & $18.503 \pm 8.765$ \\
\hline & $K_{\mathrm{O} D}\left[\mathrm{~mol}^{2} / \mathrm{kI}^{2}\right]$ & $1.48 \times 10^{-6} \pm$ & $1.40 \times 10^{-6} \pm$ & $1.35 \times 10^{-6} \pm$ \\
\hline & $\left.K_{D R}\left[\mathrm{~mol}^{-} / \mathrm{k}\right]^{2}\right]$ & $2.96 \times 10^{-7}$ & $2.07 \times 10^{-7}$ & $1.35 \times 10^{-7}$ \\
\hline & $E[\mathrm{~kJ} / \mathrm{mol}]$ & $0.580 \pm 0.043$ & $0.598 \pm 0.040$ & $0.609 \pm 0.043$ \\
\hline & $R^{2}$ & 0.881 & 0.917 & 0.421 \\
\hline
\end{tabular}

In agreement with the Temkin model, the adsorption of ADY molecules on the KPs causes a linear decrease in adsorption heat $(\Delta H)$ [57]. The enthalpy variation in the system will be negative $\left(\Delta H=H_{t}-H_{0} ; H_{t}<H_{0}\right)$; then, energy is lost [57-59]. By the second principle of thermodynamics, there will be an increase in the system's entropy. Therefore, at the equilibrium state, the system entropy is higher accordingly with an exothermic adsorption process. A small experiment supported this interpretation. It was verified that the temperature of $50 \mathrm{~mL}$ of ADY dye solution in agitation with $0.5 \mathrm{~g}$ of RC particles increased from $22.2^{\circ} \mathrm{C}$ to $25.5^{\circ} \mathrm{C}$ in $60 \mathrm{~min}$. Three solutions were placed in agitation in a container with thermal insulating walls. One contained only water, the second [water + clay], and the third [water + clay + dye]. After 60 minutes, we measured the temperature 
of each solution. The solution's temperature had increased 0.5, 0.6, and 3.3 degrees Celsius, in the container with water, with water+clay, and with water+clay+dye, respectively. The $\mathrm{CNB}$ and ADY desorption experiments (not reported here) verify that the CNB adsorption is not reversible. In contrast, the ADY adsorption is reversible, in agreement with the adsorption mechanism above proposed.

Figure 9 shows the adsorption data at equilibrium at different initial adsorbent dosages. For the sake of comparison, the dashed lines represent the theoretical data predicted by the LM (Figure 9a) and by the TM (Figure 9b).
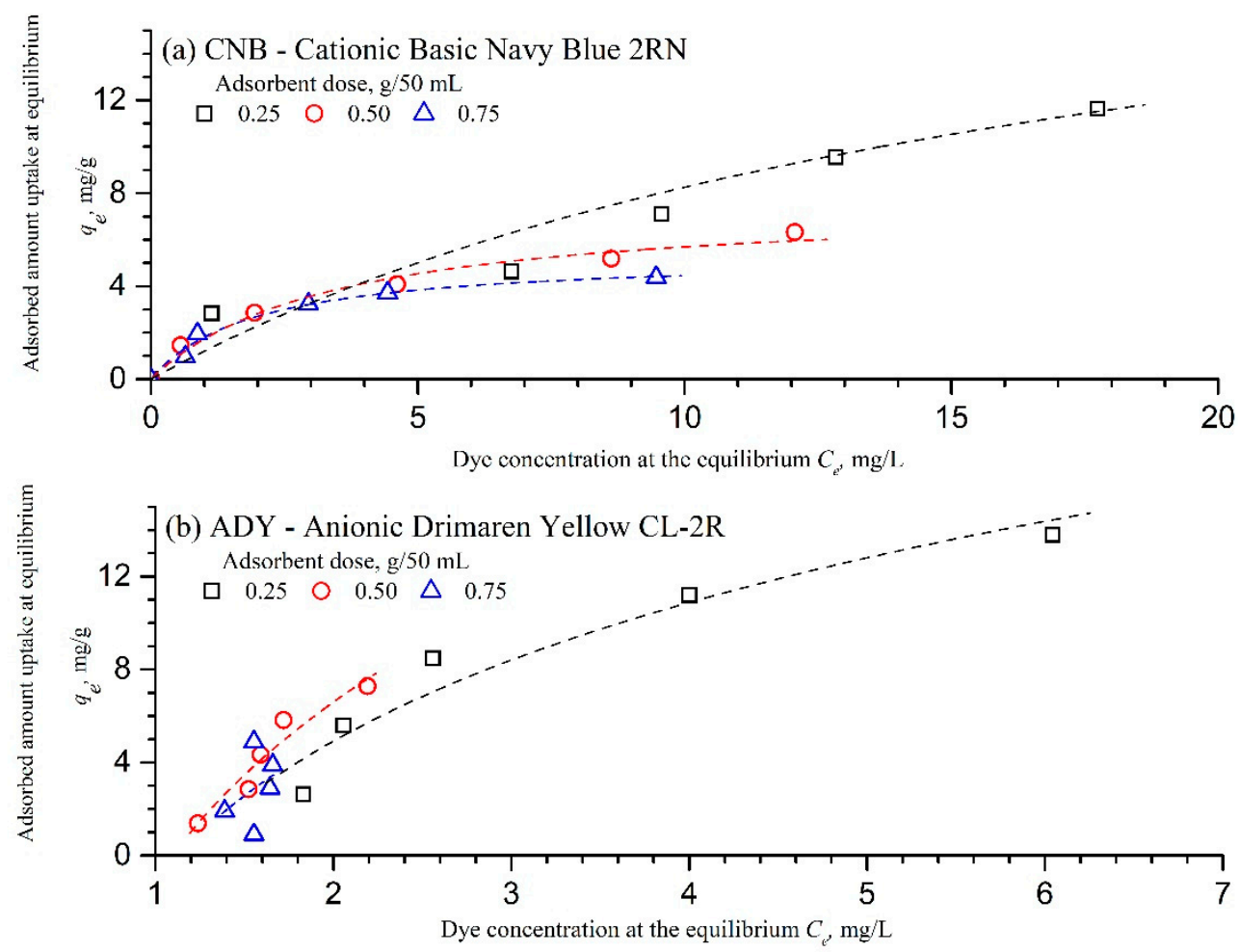

Figure 9. Adsorption data at equilibrium at different initial adsorbent dosages; each couple of $q_{e}$ and $C_{e}$ values lead to one point that results from an initial dye concentration $C_{o}$ of $15,30,45,60$, and $75 \mathrm{mg} / \mathrm{L} ; \mathrm{T}=20{ }^{\circ} \mathrm{C}$. (a) Adsorption data at equilibrium for the CNB. The dashed line represents the theoretical data predicted by the LM, Equation (4). (b) Adsorption data at equilibrium for the ADY. The dashed line represents the theoretical data predicted by the TM, Equation (7).

\subsection{Adsorption Kinetic}

The PSOM fits the CNB and ADY dye adsorption kinetic data on RC particles (Tables 7 and 8). In contrast, the PFOM does not fit the experimental CNB and ADY adsorption data. The PFOM leads to adsorption capacity values at equilibrium $q_{e}$ that are entirely different from the actual ones, determined experimentally. The differences are significant despite the relatively high quality of the PFOM fits. In contrast, the PSOM leads to $q_{e}$ values similar to the determined experimentally and high $\mathrm{R}^{2}$ values with the experimental data. The $\mathrm{R}^{2}$ values of the PSOM fit are consistently higher than the $\mathrm{R}^{2}$ values of the PFOM fit. 
Table 7. Results of the kinetic models considered for CNB-Basic Navy Blue Dye 2RN.

\begin{tabular}{|c|c|c|c|c|c|c|c|c|c|c|c|}
\hline \multirow[b]{2}{*}{$\begin{array}{l}\text { Adsorbent } \\
\text { (g/50 mL) }\end{array}$} & \multirow[b]{2}{*}{$\begin{array}{l}\text { Dye } \\
\text { (mg/L) }\end{array}$} & \multirow[b]{2}{*}{$\begin{array}{c}q_{e}^{\exp } \\
(\mathrm{mg} / \mathrm{g})\end{array}$} & \multicolumn{3}{|c|}{ Pseudo-First-Order } & \multicolumn{3}{|c|}{ Pseudo-Second-Order } & \multicolumn{3}{|c|}{ Intraparticle Diffusion } \\
\hline & & & $q_{e}(\mathrm{mg} / \mathrm{g})$ & $k_{1}\left(\min ^{-1}\right)$ & $R^{2}$ & $q_{e}(\mathrm{mg} / \mathrm{g})$ & $k_{2}(\mathrm{~g} / \mathrm{mg} \cdot \mathrm{min})$ & $R^{2}$ & $\begin{array}{c}K_{i p d} \\
\left(\mathrm{mg} / \mathrm{g} \mathrm{min}^{0.5}\right)\end{array}$ & $C(\mathrm{mg} / \mathrm{g})$ & $R^{2}$ \\
\hline \multirow{5}{*}{0.25} & 15 & 2.760 & $3.293 \pm 0.113$ & $0.262 \pm 0.093$ & 0.944 & $2.831 \pm 0.105$ & $0.186 \pm 0.026$ & 1.000 & $0.005 \pm 0.007$ & $2.731 \pm 1.210$ & 0.251 \\
\hline & 30 & 4.384 & $4.983 \pm 0.145$ & $0.272 \pm 0.087$ & 0.984 & $4.629 \pm 0.275$ & $0.152 \pm 0.038$ & 0.998 & $0.052 \pm 0.007$ & $5.045 \pm 1.249$ & 0.174 \\
\hline & 45 & 7.100 & $7.575 \pm 0.387$ & $0.194 \pm 0.090$ & 0.972 & $7.102 \pm 0.643$ & $0.196 \pm 0.028$ & 0.999 & $0.128 \pm 0.021$ & $8.313 \pm 1.267$ & 0.699 \\
\hline & 60 & 9.300 & $10.766 \pm 0.553$ & $0.246 \pm 0.082$ & 0.980 & $9.548 \pm 1.151$ & $0.267 \pm 0.047$ & 0.997 & $0.249 \pm 0.025$ & $12.128 \pm 1.412$ & 0.929 \\
\hline & 75 & 11.267 & $12.754 \pm 0.673$ & $0.273 \pm 0.112$ & 0.969 & $11.641 \pm 1.700$ & $0.600 \pm 0.052$ & 0.996 & $0.434 \pm 0.029$ & $16.094 \pm 1.737$ & 0.983 \\
\hline \multirow{5}{*}{0.50} & 15 & 1.442 & $1.627 \pm 0.159$ & $0.418 \pm 0.067$ & 0.958 & $1.456 \pm 0.032$ & $0.465 \pm 0.038$ & 0.999 & $0.001 \pm 0.0003$ & $1.414 \pm 0.987$ & 0.455 \\
\hline & 30 & 2.795 & $2.749 \pm 0.053$ & $0.271 \pm 0.050$ & 0.983 & $2.862 \pm 0.108$ & $0.127 \pm 0.021$ & 0.999 & $0.001 \pm 0.0003$ & $2.749 \pm 0.673$ & 0.496 \\
\hline & 45 & 4.015 & $4.195 \pm 0.114$ & $0.276 \pm 0.085$ & 0.964 & $4.086 \pm 0.213$ & $0.161 \pm 0.021$ & 0.999 & $0.033 \pm 0.0022$ & $4.334 \pm 0.215$ & 0.210 \\
\hline & 60 & 5.092 & $5.352 \pm 0.162$ & $0.252 \pm 0.105$ & 0.982 & $5.190 \pm 0.341$ & $0.190 \pm 0.030$ & 1.000 & $0.075 \pm 0.0029$ & $5.858 \pm 0.736$ & 0.843 \\
\hline & 75 & 6.233 & $6.593 \pm 0.195$ & $0.221 \pm 0.112$ & 0.988 & $6.322 \pm 0.507$ & $0.850 \pm 0.068$ & 0.999 & $0.120 \pm 0.0102$ & $7.522 \pm 0.785$ & 0.906 \\
\hline \multirow{5}{*}{0.75} & 15 & 0.957 & $1.353 \pm 0.254$ & $0.334 \pm 0.120$ & 0.969 & $0.963 \pm 0.017$ & $1.271 \pm 0.098$ & 1.000 & $0.001 \pm 0.0002$ & $0.959 \pm 0.178$ & 0.446 \\
\hline & 30 & 1.939 & $1.980 \pm 0.123$ & $0.422 \pm 0.105$ & 0.974 & $1.953 \pm 0.054$ & $0.561 \pm 0.025$ & 1.000 & $0.004 \pm 0.0002$ & $1.885 \pm 0.165$ & 0.500 \\
\hline & 45 & 2.793 & $3.496 \pm 0.245$ & $0.244 \pm 0.154$ & 0.959 & $3.239 \pm 0.106$ & $0.351 \pm 0.012$ & 0.999 & $0.010 \pm 0.0057$ & $2.870 \pm 0.125$ & 0.523 \\
\hline & 60 & 3.689 & $3.684 \pm 0.096$ & $0.381 \pm 0.076$ & 0.999 & $3.722 \pm 0.183$ & $0.264 \pm 0.027$ & 0.999 & $0.013 \pm 0.0068$ & $3.784 \pm 0.978$ & 0.857 \\
\hline & 75 & 4.336 & $4.531 \pm 0.187$ & $0.246 \pm 0.089$ & 0.976 & $4.386 \pm 0.248$ & $0.228 \pm 0.038$ & 1.000 & $0.048 \pm 0.0092$ & $4.857 \pm 0.132$ & 0.982 \\
\hline
\end{tabular}

Table 8. Results of kinetic models considered for ADY-Drimaren Yellow Dye CL-2R.

\begin{tabular}{|c|c|c|c|c|c|c|c|c|c|c|c|}
\hline \multirow[b]{2}{*}{$\begin{array}{l}\text { Adsorbent } \\
\text { (g/50 mL) }\end{array}$} & \multirow[b]{2}{*}{$\begin{array}{l}\text { Dye } \\
(\mathrm{mg} / \mathrm{L})\end{array}$} & \multirow[b]{2}{*}{$\begin{array}{c}q_{e}^{\exp } \\
(\mathrm{mg} / \mathrm{g})\end{array}$} & \multicolumn{3}{|c|}{ Pseudo-First-Order } & \multicolumn{3}{|c|}{ Pseudo-Second-Order } & \multicolumn{3}{|c|}{ Intraparticle Diffusion } \\
\hline & & & $q_{e}(\mathrm{mg} / \mathrm{g})$ & $k_{1}\left(\min ^{-1}\right)$ & $R^{2}$ & $q_{e}(\mathrm{mg} / \mathrm{g})$ & $\begin{array}{c}k_{2} \\
(\mathrm{~g} / \mathrm{mg} \cdot \mathrm{min})\end{array}$ & $R^{2}$ & $\begin{array}{c}K_{i p d} \\
\left(\mathrm{mg} / \mathrm{g} \mathrm{min}^{0.5}\right)\end{array}$ & $C(\mathrm{mg} / \mathrm{g})$ & $R^{2}$ \\
\hline \multirow{5}{*}{0.25} & 15 & 2.634 & $2.522 \pm 0.167$ & $10.228 \pm 0.895$ & 0.986 & $2.627 \pm 0.043$ & $1.253 \pm 0.901$ & 0.999 & $0.007 \pm 0.004$ & $2.669 \pm 0.085$ & 0.280 \\
\hline & 30 & 5.589 & $5.412 \pm 0.484$ & $2.000 \pm 0.328$ & 0.969 & $5.597 \pm 0.082$ & $0.237 \pm 0.053$ & 0.999 & $0.003 \pm 0.001$ & $5.494 \pm 0.149$ & 0.487 \\
\hline & 45 & 8.488 & $8.231 \pm 0.231$ & $0.363 \pm 0.127$ & 0.992 & $8.518 \pm 0.121$ & $0.120 \pm 0.005$ & 0.999 & $0.023 \pm 0.002$ & $8.165 \pm 0.168$ & 0.009 \\
\hline & 60 & 11.200 & $10.936 \pm 1.265$ & $0.277 \pm 0.159$ & 0.979 & $11.246 \pm 0.116$ & $0.099 \pm 0.002$ & 1.000 & $0.040 \pm 0.003$ & $10.710 \pm 0.149$ & 0.505 \\
\hline & 75 & 13.791 & $13.584 \pm 1.176$ & $0.256 \pm 0.186$ & 0.989 & $13.875 \pm 0.093$ & $0.072 \pm 0.008$ & 1.000 & $0.067 \pm 0.005$ & $13.041 \pm 0.159$ & 0.959 \\
\hline \multirow{5}{*}{0.50} & 15 & 1.376 & $1.399 \pm 0.095$ & $0.295 \pm 0.173$ & 0.984 & $1.377 \pm 0.032$ & $7.917 \pm 3.995$ & 1.000 & $0.001 \pm 0.0003$ & $1.365 \pm 0.313$ & 0.103 \\
\hline & 30 & 2.848 & $2.879 \pm 0.112$ & $0.395 \pm 0.159$ & 0.998 & $2.850 \pm 0.079$ & $2.863 \pm 1.238$ & 1.000 & $0.002 \pm 0.0006$ & $2.836 \pm 0.189$ & 0.198 \\
\hline & 45 & 4.341 & $4.320 \pm 0.173$ & $0.490 \pm 0.198$ & 0.988 & $4.344 \pm 0.004$ & $1.739 \pm 1.550$ & 1.000 & $0.002 \pm 0.0001$ & $4.313 \pm 0.814$ & 0.531 \\
\hline & 60 & 5.828 & $5.704 \pm 0.120$ & $4.411 \pm 1.205$ & 1.000 & $5.836 \pm 0.019$ & $0.578 \pm 0.188$ & 1.000 & $0.005 \pm 0.0006$ & $5.756 \pm 0.380$ & 0.202 \\
\hline & 75 & 7.281 & $7.260 \pm 0.183$ & $0.359 \pm 0.254$ & 0.976 & $7.291 \pm 0.052$ & $0.736 \pm 0.067$ & 1.000 & $0.008 \pm 0.0009$ & $7.197 \pm 0.703$ & 0.959 \\
\hline \multirow{5}{*}{0.75} & 15 & 0.896 & $0.826 \pm 0.095$ & $0.175 \pm 0.125$ & 0.986 & $0.902 \pm 0.016$ & $4.122 \pm 2.300$ & 0.999 & $0.003 \pm 0.003$ & $0.873 \pm 0.045$ & 0.315 \\
\hline & 30 & 1.907 & $1.832 \pm 0.129$ & $0.262 \pm 0.181$ & 0.979 & $1.919 \pm 0.009$ & $0.827 \pm 0.662$ & 1.000 & $0.009 \pm 0.005$ & $1.822 \pm 0.273$ & 0.590 \\
\hline & 45 & 2.890 & $2.808 \pm 0.205$ & $0.311 \pm 0.178$ & 0.989 & $2.900 \pm 0.009$ & $1.042 \pm 0.643$ & 1.000 & $0.007 \pm 0.003$ & $2.823 \pm 0.247$ & 0.520 \\
\hline & 60 & 3.889 & $3.870 \pm 0.178$ & $0.329 \pm 0.214$ & 0.990 & $3.900 \pm 0.016$ & $1.235 \pm 0.364$ & 1.000 & $0.007 \pm 0.005$ & $3.820 \pm 0.546$ & 0.197 \\
\hline & 75 & 4.896 & $4.772 \pm 0.223$ & $0.313 \pm 0.205$ & 0.984 & $4.914 \pm 0.019$ & $0.565 \pm 0.183$ & 1.000 & $0.013 \pm 0.004$ & $4.771 \pm 0.985$ & 0.407 \\
\hline
\end{tabular}

Similarly, the IPDM fitted the CNB and ADY adsorption data when the adsorbate's concentration was the highest $(75 \mathrm{mg} / \mathrm{L})$ (Tables 7 and 8). The interparticle diffusion is not the limiting step in the CNB and ADY adsorption on RC particles at a concentration lower than $75 \mathrm{mg} / \mathrm{L}$.

The $\mathrm{R}^{2}$ value is greater than 0.996 and 0.999 for the CNB and ADY adsorption kinetics, respectively, which indicates that it is a reasonably good fit between the PSOM and the experimental data in both sets of experiments. The excellent agreement between the experimental values $q_{e}^{\exp }$ and calculated values $q_{e}$ indicates that the CNB and ADY adsorption were suitable for PSOM.

The rate constant for the CNB adsorption onto RC particles varies ten times between 0.127 to $1.271 \mathrm{~g} / \mathrm{mg} \cdot \mathrm{min}$. The rate constant for the ADY adsorption onto RC particles varies 100 times between 0.072 to $7.917 \mathrm{~g} / \mathrm{mg} \cdot \mathrm{min}$. These results could support the hypothesis that CNB adsorption proceeds by forming a chemisorbed monolayer. The ADY proceeds by forming a physisorbed monolayer. However, more studies need to be done to resolve this issue.

Figure 10 shows the adsorption kinetic profiles of ADY and CNB dyes onto RC particles at different initial adsorbent dosages and dye concentrations. For the sake of the analysis, the dashed lines are the theoretical data predicted by the PSOM, Equation (13). 


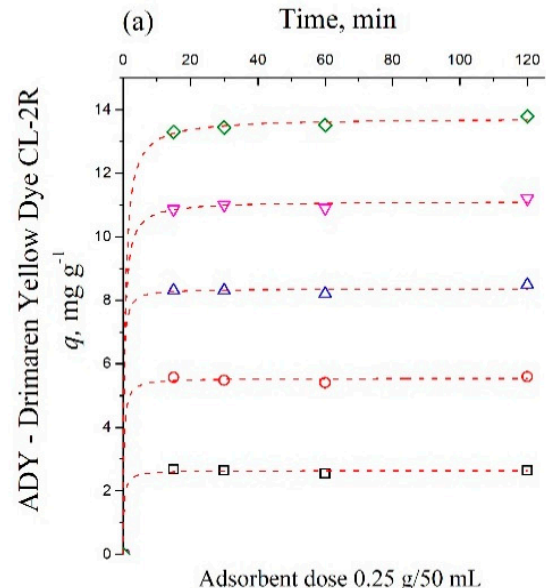

(d)

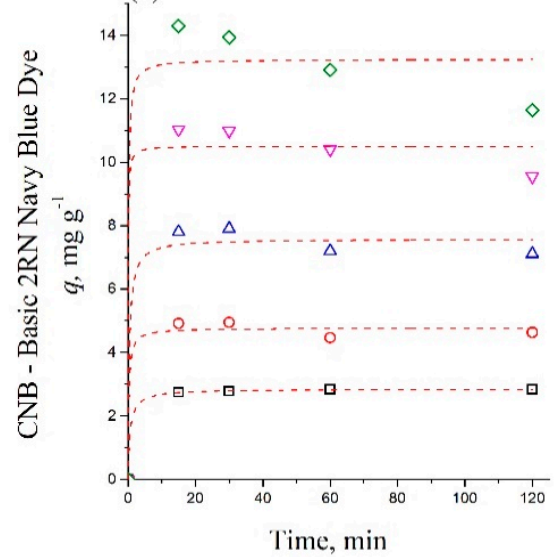

(b) Time, $\min$

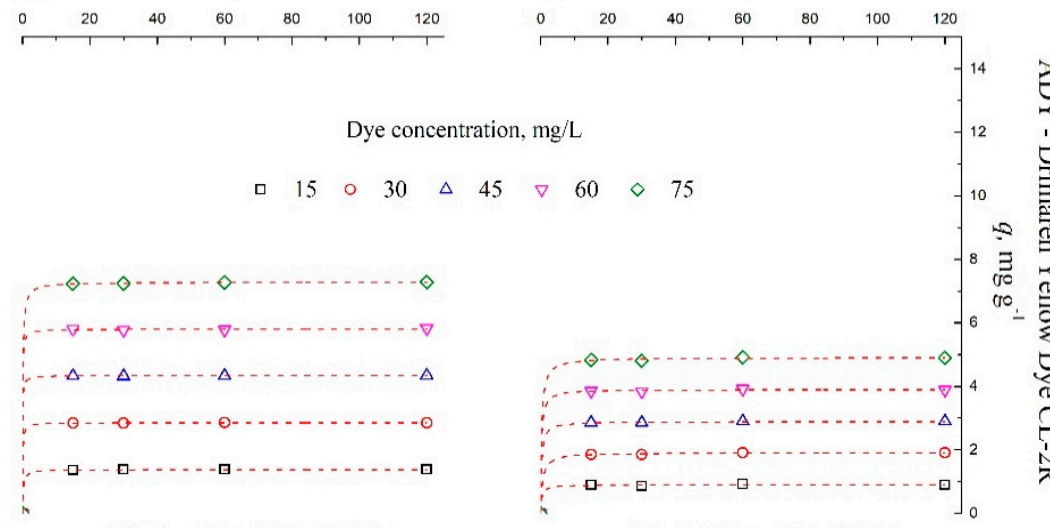

(e)

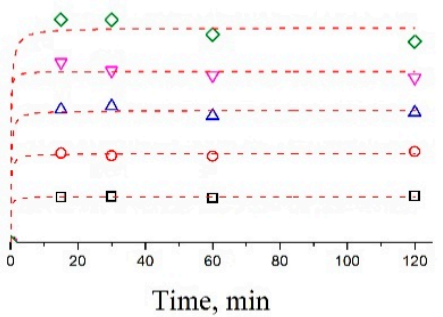

(f)

(c) Time, $\min$

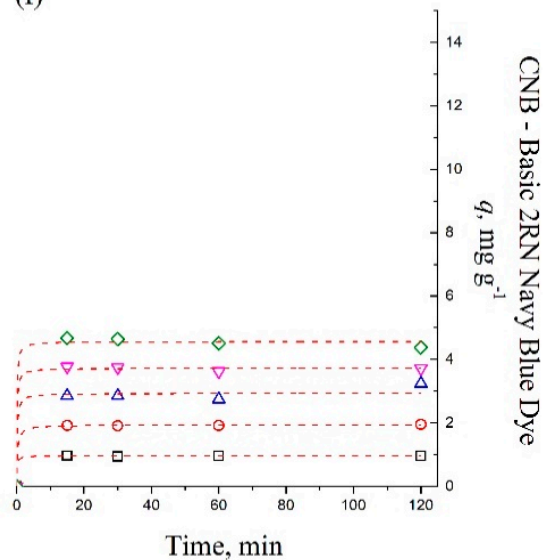

Figure 10. Adsorption kinetic profiles of ADY $(\mathbf{a}-\mathbf{c})$ and $\mathrm{CNB}(\mathbf{d}-\mathbf{f})$ dyes onto RC particles at different initial adsorbent dosages and dye concentrations; $\mathrm{T}=20^{\circ} \mathrm{C}$. The dashed lines are the theoretical data predicted by the PSOM, Equation (13).

\section{Conclusions}

The naturally occurring clayey composite RC can efficiently remove the cationic and anionic dye, like the $\mathrm{CNB}$ and $\mathrm{ADY}$, from water. The outcomes suggest a clayey composite constituted by IPs, KPs, and LPs. The heterogeneous composition of naturally occurring clayey composite favors different adsorption mechanisms. It opens an avenue for the separation process's engineering. The IPs showed a strong affinity for CNB dye and the KPs and LPs for ADY dye.

The proposed framework for studying the dye concentration effect on the adsorption capacity leads to the adsorbent dose for complete adsorption. At a $\mathrm{pH}$ of less than 4 , the CNB and ADY removal percentage was $97 \%$ and $96 \%$, respectively. At a $\mathrm{pH}$ greater than 8 , the CNB and ADY removal was $75 \%$ and $25 \%$, respectively. The study of the $\mathrm{pH}$ effect on dye removal allowed us to postulate the RC particles' CNB and ADY adsorption mechanisms. The CNB adsorption happened by chemisorption of a monolayer on IPs. In contrast, the ADY adsorption occurs by the physisorption of a monolayer on KPs.

The Langmuir isotherm model fits very well with CNB experimental data. The Temkin model shows the best fit between the isotherm function and the ADY dye-adsorption data. The PSOM fits the CNB and ADY dye adsorption kinetic data on RC particles. The interparticle diffusion is not the limiting step in the CNB and ADY adsorption on RC particles at a concentration lower than $75 \mathrm{mg} / \mathrm{g}$.

Author Contributions: Conceptualization and methodology, C.O.M. and V.J.G., software, C.O.M. and V.J.G., validation, J.R.G., formal analysis, V.J.G., F.F.-M. investigation, C.O.M. and V.J.G., resources, C.O.M. and V.J.G., writing—original draft preparation, J.R.G., C.O.M., V.J.G. and F.F.-M. writing- 
review V.J.G., visualization, A.C.R., supervision, A.C.R., project administration, A.C.R. All authors have read and agreed to the published version of the manuscript.

Funding: This research received no external funding.

Institutional Review Board Statement: Not applicable.

Informed Consent Statement: Not applicable.

Data Availability Statement: The data presented in this study are available on request from the corresponding author.

Acknowledgments: The authors declare express gratitude to the Vice-Rectorate of Post Graduate Studies and Research of the Universidad Nacional de Chimborazo (UNACH) through the Interdisciplinary Studies research group.

Conflicts of Interest: The authors declare no conflict of interest.

\section{Abbreviations}

\begin{tabular}{|c|c|}
\hline ADY & Anionic Drimaren Yellow CL-2R \\
\hline $\mathrm{RC}$ & Red clay \\
\hline IPs & Iron-containing particles \\
\hline $\mathrm{H}$ & Hematite \\
\hline M & Magnesiochloritoid \\
\hline EDS & Energy-dispersive spectroscopy \\
\hline XRD & X-ray diffraction \\
\hline$C_{e} ; \mathrm{mg} \mathrm{L}^{-1}$ & Dye concentration at the equilibrium \\
\hline$q_{e} ; \mathrm{mg} \mathrm{g}^{-1}$ & Adsorption capacity or adsorbed amount uptake at equilibrium \\
\hline$C_{0} ; \mathrm{mg} \mathrm{L}^{-1}$ & Initial dye concentration \\
\hline$T ; \mathrm{K}$ & Temperature \\
\hline LM & Langmuir model \\
\hline$R_{L}$ & The separation factor or equilibrium parameter \\
\hline FM & Freundlich model \\
\hline TM & Temkin model \\
\hline$R T / b_{T} ; \mathrm{J} \mathrm{mol}^{-1}$ & Adsorption energy \\
\hline D-RM & Dubinin-Radushkevich model \\
\hline$E ; \mathrm{kJ} \mathrm{mol}^{-1}$ & The average adsorption energy \\
\hline PFOM & Pseudo-first-order model \\
\hline PSOM & Pseudo-second-order model \\
\hline$C ; \mathrm{mg} \mathrm{g}^{-1}$ & Constant associated with the boundary layer thickness \\
\hline$q_{t} ; \mathrm{mg} \mathrm{g}^{-1}$ & Amount of adsorbate adsorbed at any $t(\mathrm{~min})$ \\
\hline IPDM & Intra-particle diffusion model \\
\hline$h_{0} ; \mathrm{mg} / \mathrm{g} \times \min$ & Initial adsorption rate \\
\hline CNB & Cationic Basic Navy Blue 2RN \\
\hline KPs & Kaolinite particles \\
\hline K & Kaolinite \\
\hline $\mathrm{L}$ & Laumontite \\
\hline LPs & Laumontite particles \\
\hline DR & Diffuse reflectance \\
\hline$V ; \mathrm{L}$ & Solution total volume \\
\hline$m ; \mathrm{g}$ & Absorbent mass \\
\hline$q_{m} ; \mathrm{mg} \mathrm{g}^{-1}$ & The maximum possible adsorption or maximum adsorption capacity \\
\hline$\% R$ & The removed adsorbate's relative amount \\
\hline$R$ & Gass ideal constant $\left(8.314 \mathrm{~J} \mathrm{~mol}^{-1} \mathrm{~K}^{-1}\right)$ \\
\hline$K_{L} ; \mathrm{L} \mathrm{mg}^{-1}$ & A constant related to the affinity between an adsorbent and adsorbate \\
\hline$n$ & Freundlich intensity parameter \\
\hline$K_{F} ;(\mathrm{mg} / \mathrm{g}) /(\mathrm{mg} / \mathrm{L})^{n}$ & Freundlich constant \\
\hline
\end{tabular}




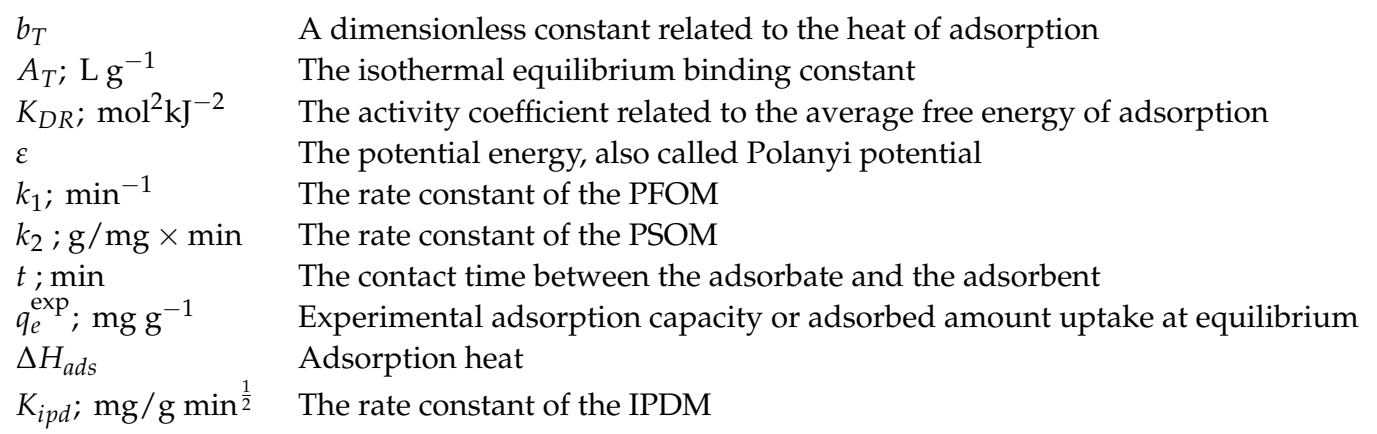

\section{References}

1. Gupta, V.K. Suhas Application of low-cost adsorbents for dye removal-A review. J. Environ. Manag. 2009, 90, $2313-2342$. [CrossRef]

2. Rodell, M.; Famiglietti, J.S.; Wiese, D.N.; Reager, J.T.; Beaudoing, H.K.; Landerer, F.W.; Lo, M.H. Emerging trends in global freshwater availability. Nature 2018, 557, 651-659. [CrossRef] [PubMed]

3. Kausar, A.; Iqbal, M.; Javed, A.; Aftab, K.; Nazli, Z.I.H.; Bhatti, H.N.; Nouren, S. Dyes adsorption using clay and modified clay: A review. J. Mol. Liq. 2018, 256, 395-407. [CrossRef]

4. Zhou, Y.; Lu, J.; Zhou, Y.; Liu, Y. Recent advances for dyes removal using novel adsorbents: A review. Environ. Pollut. 2019, 252, 352-365. [CrossRef] [PubMed]

5. Hao, Y.F.; Yan, L.G.; Yu, H.Q.; Yang, K.; Yu, S.J.; Shan, R.R.; Du, B. Comparative study on adsorption of basic and acid dyes by hydroxy-aluminum pillared bentonite. J. Mol. Liq. 2014, 199, 202-207. [CrossRef]

6. Yang, F.; Tian, J.; Meersmans, J.; Fang, H.; Yang, H.; Lou, Y.; Li, Z.; Liu, K.; Zhou, Y.; Blagodatskaya, E.; et al. Functional soil organic matter fractions in response to long-term fertilization in upland and paddy systems in South China. Catena 2018, 162, 270-277. [CrossRef]

7. Xu, D.; Ma, W.; Chen, S.; Jiang, Q.; He, K.; Shi, Z. Assessment of important soil properties related to Chinese Soil Taxonomy based on vis-NIR reflectance spectroscopy. Comput. Electron. Agric. 2018, 144, 1-8. [CrossRef]

8. Sarma, G.K.; Gupta, S.; Bhattacharyya, K.G. Removal of hazardous basic dyes from aqueous solution by adsorption onto kaolinite and acid-treated kaolinite: Kinetics, isotherm and mechanistic study. SN Appl. Sci. 2019, 1, 1-15. [CrossRef]

9. Lucena, G.; Da Silva, A.; Castgro, L.; Dos Santos, V. Removal of textile dyes from aqueous solutions by modified chitosan with thioacetamide. Rev. Ambient. Agua 2013, 8, 144-154. [CrossRef]

10. Wu, Y.H.; Hu, Y.; Xie, Z.W.; Feng, S.X.; Li, B.; Mi, X.M. Characterization of biosorption process of acid orange 7 on waste brewery's yeast. Appl. Biochem. Biotechnol. 2011, 163, 882-894. [CrossRef] [PubMed]

11. Zhou, Y.; Zhang, R.; Gu, X.; Lu, J. Adsorption of Divalent Heavy Metal Ions from Aqueous Solution by Citric Acid Modified Pine Sawdust. Sep. Sci. Technol. 2015, 50, 245-252. [CrossRef]

12. Lin, Z.; Puls, R.W. Adsorption, desorption and oxidation of arsenic affected by clay minerals and aging process. Environ. Geol. 2000, 39, 753-759. [CrossRef]

13. Silva, T.L.; Ronix, A.; Pezoti, O.; Souza, L.S.; Leandro, P.K.T.; Bedin, K.C.; Beltrame, K.K.; Cazetta, A.L.; Almeida, V.C. Mesoporous activated carbon from industrial laundry sewage sludge: Adsorption studies of reactive dye Remazol Brilliant Blue R. Chem. Eng. J. 2016, 303, 467-476. [CrossRef]

14. Bentahar, S.; Dbik, A.; El Khomri, M.; El Messaoudi, N.; Lacherai, A. Removal of a cationic dye from aqueous solution by natural clay. Groundw. Sustain. Dev. 2018, 6, 255-262. [CrossRef]

15. Yan, L.G.; Qin, L.L.; Yu, H.Q.; Li, S.; Shan, R.R.; Du, B. Adsorption of acid dyes from aqueous solution by CTMAB modified bentonite: Kinetic and isotherm modeling. J. Mol. Liq. 2015, 211, 1074-1081. [CrossRef]

16. Chaari, I.; Fakhfakh, E.; Medhioub, M.; Jamoussi, F. Comparative study on adsorption of cationic and anionic dyes by smectite rich natural clays. J. Mol. Struct. 2019, 1179, 672-677. [CrossRef]

17. Saif Ur Rehman, M.; Munir, M.; Ashfaq, M.; Rashid, N.; Nazar, M.F.; Danish, M.; Han, J.I. Adsorption of Brilliant Green dye from aqueous solution onto red clay. Chem. Eng. J. 2013, 228, 54-62. [CrossRef]

18. Ali, L.; Alhassani, H.; Karuvantevida, N.; Rauf, M.; Ashraf, S. Efficient aerobic degradation of various azo dyes by a Sphingomonas sp isolated from petroleum sludge. J. Bioremediation Biodegrad. 2014, 5, 3. [CrossRef]

19. Kandisa, R.V.; Saibaba KV, N. Dye Removal by Adsorption: A Review. J. Bioremediation Biodegrad. 2016, 7, 371. [CrossRef]

20. Altomare, A.; Corriero, N.; Cuocci, C.; Falcicchio, A.; Moliterni, A.; Rizzi, R. QUALX2.0: A qualitative phase analysis software using the freely available database POW-COD. J. Appl. Crystallogr. 2015, 48, 598-603. [CrossRef]

21. Al-Ghouti, M.A.; Da'ana, D.A. Guidelines for the use and interpretation of adsorption isotherm models: A review. J. Hazard. Mater. 2020, 393, 122383. [CrossRef]

22. Langmuir, I. The adsorption of gases on plane surfaces of glass, mica, and platinum. J. Am. Chem. Soc. 1918, 40, 1361-1403. [CrossRef]

23. Tran, H.N.; You, S.J.; Hosseini-Bandegharaei, A.; Chao, H.P. Mistakes and inconsistencies regarding adsorption of contaminants from aqueous solutions: A critical review. Water Res. 2017, 120, 88-116. [CrossRef] 
24. Salvestrini, S. A modification of the Langmuir rate equation for diffusion-controlled adsorption kinetics. React. Kinet. Mech. Catal. 2019, 128, 571-586. [CrossRef]

25. Freundlich, H. Uber die adsorption in lo sungen. Z Phys. Chem. 1906, 57, 385-471.

26. Tempkin, M.I.; Pyzhev, V. Kinetics of ammonia synthesis on promoted iron catalyst. Acta Phys. Chim. USSR 1940, 12, 327-356.

27. Dubinin, M.; Radushkevich, L. Equation of the characteristic curve of activated charcoal. Dokl. Akad. Nauk. SSSR 1947, 1,875.

28. Langergren, S.K. About the theory of so-called adsorption of soluble substances. Sven. Vetenskapsakad. Handingarl 1898, 1-39.

29. Plazinski, W.; Rudzinski, W.; Plazinska, A. Theoretical models of sorption kinetics including a surface reaction mechanism: A review. Adv. Colloid Interface Sci. 2009, 152, 2-13. [CrossRef]

30. Blanchard, G.; Maunaye, M.; Martin, G. Removal of heavy metals from waters by means of natural zeolites. Water Res. 1984, 18, 1501-1507. [CrossRef]

31. Guo, X.; Wang, J. A general kinetic model for adsorption: Theoretical analysis and modeling. J. Mol. Liq. 2019, 288, 111100. [CrossRef]

32. Ho, Y.S. Review of second-order models for adsorption systems. J. Hazard. Mater. 2006, 136, 681-689. [CrossRef] [PubMed]

33. Weber, W.J.; Morris, J.C. Kinetics of adsorption on carbon from solution. J. Sanit. Eng. Div. 1963, 89, 31-60. [CrossRef]

34. Stenberg, B.; Viscarra Rossel, R.A.; Mouazen, A.M.; Wetterlind, J. Visible and Near Infrared Spectroscopy in Soil Science. Adv. Agron. 2010, 107, 163-215. [CrossRef]

35. Pearlshtien, D.H.; Ben-Dor, E. Effect of organic matter content on the spectral signature of iron oxides across the VIS-NIR spectral region in artificial mixtures: An example from a red soil from Israel. Remote Sens. 2020, 12, 1960. [CrossRef]

36. Munnaf, M.A.; Nawar, S.; Mouazen, A.M. Laboratory and On-Line Measured Vis-NIR Spectra. Remote Sens. 2019, 11, 2819. [CrossRef]

37. McDowell, M.L.; Bruland, G.L.; Deenik, J.L.; Grunwald, S.; Knox, N.M. Soil total carbon analysis in Hawaiian soils with visible, near-infrared and mid-infrared diffuse reflectance spectroscopy. Geoderma 2012, 189-190, 312-320. [CrossRef]

38. Rossel, R.A.V.; Behrens, T. Using data mining to model and interpret soil diffuse reflectance spectra. Geoderma 2010, 158, 46-54. [CrossRef]

39. Curcio, D.; Ciraolo, G.; D’Asaro, F.; Minacapilli, M. Prediction of Soil Texture Distributions Using VNIR-SWIR Reflectance Spectroscopy. Procedia Environ. Sci. 2013, 19, 494-503. [CrossRef]

40. Ben-Dor, E.; Banin, A. Near-infrared analysis as a rapid method to simultaneously evaluate several soil properties. Soil Sci. Soc. Am. J. 1995, 59, 364-372. [CrossRef]

41. De Grave, E.; Vanleerberghe, R.; Verdonck, L.; De Geyter, G. Mössbauer and infrared spectroscopic studies of Belgian chloritoids. Phys. Chem. Miner. 1984, 11, 85-94. [CrossRef]

42. Chopin, C.; Seidel, E.; Theye, T.; Ferraris, G.; Ivaldi, G.; Catti, M. Magnesiochloritoid, and the Fe-Mg series in the chloritoid group. Eur. J. Mineral. 1992, 4, 67-76. [CrossRef]

43. Ben-Dor, E.; Taylor, R.G.; Hill, J.; Demattê, J.A.M.; Whiting, M.L.; Chabrillat, S.; Sommer, S. Imaging Spectrometry for Soil Applications. Adv. Agron. 2008, 97, 321-392. [CrossRef]

44. Jagadamma, S.; Mayes, M.A.; Phillips, J.R. Selective Sorption of Dissolved Organic Carbon Compounds by Temperate Soils. PLoS ONE 2012, 7. [CrossRef]

45. Ray, S.; Gusain, R.; Kumar, N. Adsorption in the context of water purification: Fundamentals and applications. In Carbon Nanomaterials-Based Adsorbents for Water Purification; Elsevier: Amsterdam, The Netherlands, 2020; pp. 67-100.

46. Dabrowski, A. Adsorption-From theory to practice. Adv. Colloid Interface Sci. 2001, 93, 135-224. [CrossRef]

47. Sing, K.S.W. Adsorption by Active Carbons, 2nd ed.; Elsevier Ltd.: Amstrdam, The Netherlands, 2013; ISBN 9780080970356.

48. Umoren, S.A.; Etim, U.J.; Israel, A.U. Adsorption of methylene blue from industrial effluent using poly (vinyl alcohol). J. Mater. Environ. Sci. 2013, 4, 75-86.

49. Anirudhan, T.S.; Ramachandran, M. Adsorptive removal of basic dyes from aqueous solutions by surfactant modified bentonite clay (organoclay): Kinetic and competitive adsorption isotherm. Process Saf. Environ. Prot. 2015, 95, 215-225. [CrossRef]

50. Yu, X.; Wei, C.; Wu, H. Effect of molecular structure on the adsorption behavior of cationic dyes onto natural vermiculite. Sep. Purif. Technol. 2015, 156, 489-495. [CrossRef]

51. Oluwafemi, O.; Ojo, A.A. Adsorptive removal of anionic dye from aqueous solutions by mixture of Kaolin and Bentonite clay: Characteristics, isotherm, kinetic and thermodynamic studies. Iran. J. Energy Environ. 2015, 6, 147-153. [CrossRef]

52. Ngulube, T.; Gumbo, J.R.; Masindi, V.; Maity, A. An update on synthetic dyes adsorption onto clay based minerals: A state-of-art review. J. Environ. Manag. 2017, 191, 35-57. [CrossRef]

53. Safa, Y.; Bhatti, H.N. Kinetic and thermodynamic modeling for the removal of Direct Red-31 and Direct Orange-26 dyes from aqueous solutions by rice husk. Desalination 2011, 272, 313-322. [CrossRef]

54. Malakootian, M.; Mansoorian, H.J.; Yari, A. Removal of reactive dyes from aqueous solutions by a non-conventional and low cost agricultural waste: Adsorption on ash of Aloe Vera plant. Iran. J. Health Saf. Environ. 2014, 1, 117-125.

55. Togue Kamga, F. Modeling adsorption mechanism of paraquat onto Ayous (Triplochiton scleroxylon) wood sawdust. Appl. Water Sci. 2019, 9, 1-7. [CrossRef]

56. Febrianto, J.; Kosasih, A.N.; Sunarso, J.; Ju, Y.H.; Indraswati, N.; Ismadji, S. Equilibrium and kinetic studies in adsorption of heavy metals using biosorbent: A summary of recent studies. J. Hazard. Mater. 2009, 162, 616-645. [CrossRef] [PubMed]

57. Ayawei, N.; Ebelegi, A.N.; Wankasi, D. Modelling and Interpretation of Adsorption Isotherms. J. Chem. 2017, 2017. [CrossRef] 
58. Dada, A.O.; Olalekan, A.P.; Olantunya, A.; Dada, O.; Olatunya, A.M.; Dada, O. Langmuir, Freundlich, Temkin and DubininRadushkevich Isotherms Studies of Equilibrium Sorption of Zn 2+ Unto Phosphoric Acid Modified Rice Husk. IOSR J. Appl. Chem. 2012, 3, 38-45. [CrossRef]

59. Inyinbor, A.A.; Adekola, F.A.; Olatunji, G.A. Kinetics, isotherms and thermodynamic modeling of liquid phase adsorption of Rhodamine B dye onto Raphia hookerie fruit epicarp. Water Resour. Ind. 2016, 15, 14-27. [CrossRef] 